\begin{tabular}{|l|c|c|c|r|}
\hline $\begin{array}{l}\text { Cuadernos de Investigación Geográfica } \\
\text { Geographical Research Letters }\end{array}$ & 2018 & N $^{\circ} 44(1)$ & pp. 321-348 & $\begin{array}{r}\text { ISSN 0211-6820 } \\
\text { eISSN 1697-9540 }\end{array}$ \\
\hline
\end{tabular}

\title{
HOLOCENE ALLUVIAL SEQUENCE IN THE VAL DE ZARAGOZA (LOS MONEGROS) IN THE PALAEOENVIRONMENTAL CONTEXT OF THE EBRO BASIN (NE SPAIN)
}

\author{
J.L. PEÑA-MONNÉ ${ }^{1 *}$, M.M.SAMPIETRO-VATTUONE ${ }^{2}$, \\ L.A. LONGARES-ALADRÉN ${ }^{1}$, F. PÉREZ-LAMBÁN ${ }^{3}$, \\ M. SÁNCHEZ-FABRE ${ }^{1}$, M. ALCOLEA-GRACIA ${ }^{4}$, L. VALLÉS ${ }^{1}$, \\ M.T. ECHEVERRÍA-ARNEDO ${ }^{1}$, C. BARAZA ${ }^{1}$ \\ ${ }^{1}$ Departamento de Geografía y Ordenación del Territorio, IUCA, \\ Universidad de Zaragoza, 50009 Zaragoza, Spain. \\ ${ }^{2}$ Laboratorio de Geoarqueología, Universidad Nacional de Tucumán, CONICET, Argentina. \\ ${ }^{3}$ Departamento de Geografía, Prehistoria y Arqueología, \\ Universidad del País Vasco/Euskal Herriko Unibertsitatea, Vitoria, Spain. \\ ${ }^{4}$ Departamento de Ciencias de la Antigüedad, Universidad de Zaragoza, Spain.
}

\begin{abstract}
Flat-bottomed valleys formed by Holocene fills are the most characteristic landforms in the center of the Ebro basin. This paper analyzes, within a regional framework, a small fluvial basin located in the north of the Alcubierre Range. Three Holocene morphosedimentary units (H1-H3) and a sub-functional level (H4) are identified. These units are representative of the regional geomorphological evolutionary process in the Ebro basin. New chronological insights on climate and landscape management are provided by a study of the Bastarás weir, a construction made for water flow management during the Little Ice Age (LIA). The integration of Val de Zaragoza radiocarbon datings into the regional framework enables the authors to identify the main formation stages, as well as the influence of climatic and human factors on its evolution. The intensification of human pressure in the territory is reflected in a progressive increase in sediment accumulation rates in the valleys, peaking during Roman times and the Little Ice Age.
\end{abstract}

Secuencia aluvial holocena de la Val de Zaragoza (Monegros) en el contexto paleoambiental de la cuenca del Ebro (NE España)

RESUMEN. Los valles de fondo plano formados por rellenos holocenos constituyen los paisajes más característicos del sector central de la cuenca del Ebro. En este trabajo se analiza una pequeña cuenca fluvial localizada en el norte de la Sierra de Alcubierre, en la que se han identificado tres unidades morfosedimentarias holocenas (H1-H3) y un nivel subfuncional (H4), que son representativos de la evolución geomorfológica regional de la Cuenca del Ebro. Uno de los aspectos más relevantes del 
valle lo constituye el azud de Bastarás, construcción realizada durante la Pequeña Edad del Hielo para el aprovechamiento del agua, que aporta nuevos datos cronológicos sobre dicha época y acerca de la gestión del territorio. La integración de las dataciones radiocarbónicas obtenidas en la Val de Zaragoza en un marco regional ha permitido precisar las principales etapas de formación de los valles de fondo plano, así como la importancia de los factores climáticos y humanos en su evolución. La intensificación de la presión humana sobre el territorio queda reflejada en un progresivo aumento en las tasas de acumulación de sedimentos en los valles, alcanzando sus picos máximos en Época Romana y en la Pequeña Edad del Hielo.

Key words: Holocene, Roman period, LIA, paleoenvironments, geoarchaeology.

Palabras clave: Holoceno, Época Romana, PEH, paleoambientes, geoarqueología.

Received: 3 July 2017

Accepted: 30 July 2017

Corresponding author: José Luis Peña-Monné, Departamento de Geografía y Ordenación del Territorio e IUCA, Facultad de Filosofía y Letras, 50009 Zaragoza, Spain. E-mail address: jlpena@unizar.es

\section{Introduction}

Holocene sedimentary records are of great importance for understanding environmental changes related to climatic fluctuations and human impact on the landscape. Studying these records requires several interdisciplinary tools and analytical methods to produce paleoenvironmental reconstructions and evolutionary models, such as those used in various geoarchaeological studies (Peña Monné et al., 2005; Peña-Monné and Sampietro-Vattuone, 2014). Drylands are most suitable areas for this type of study, because of their environmental fragility and the quick response of geomorphological processes to landscape changes. Thus, it is not surprising that pioneering research of geoarchaeological interest was carried out in the Mediterranean area (Vita-Finzi, 1969; Pope and Van Andel, 1984; Brückner, 1986; Bintliff, 2002; Butzer, 2005).

The Holocene records most commonly used for paleoenvironmental reconstructions in NE Spain are valley bottoms and slope accumulations. At the center of the Ebro depression, the bottoms of the fluvial valleys surrounding the city of Zaragoza (Figs. $1 \mathrm{a}, \mathrm{b})$ have a flat morphology due to Holocene infilling processes. These flat-bottom valleys are locally known as vales and are carved on an evaporitic substratum made up of alternating gypsum, marl and glauberite beds (Salvany et al., 2007).

These lithologies show a fast geomorphological response to environmental changes caused by natural or anthropogenic forces. For this reason, the vales of the middle section of the Ebro Basin were the focus of several geomorphological studies and paleoenvironmental reconstructions. In this central sector of the Ebro basin, the studies has focused on the Huerva and Ginel Rivers and Valmadrid flat-bottom valley, all of which are right side tributaries of the Ebro River (Van Zuidam, 1975; 
Burillo et al., 1985; Soriano and Calvo, 1987; Soriano, 1989; Peña Monné, 1996; Peña Monné et al, 1993, 1996, 2001, 2004; Arauzo and Gutierrez, 1994; Peña Monné et al., 2014). Secondly, several studies were based on the vales that descend to the left margin of the Ebro River traversing the gypsum scarp (Constante et al., 2006, 2009, 2010, 2011; Constante and Peña-Monné, 2009) and to the north of Zaragoza around the village of Leciñena (Sancho et al., 2007a). Peña Monné et al. (2014) reviewed these studies and synthesized the Holocene evolution of the center of the Ebro depression. Finally, the infilled-valleys of Bardenas Reales (Navarra) that are located $100 \mathrm{~km}$ to the NW of the study area, yield data about regional Holocene evolution (Peña Monné et al., 2006; Sancho et al., 2007b, 2008) and provide information that is used here as complementary data.

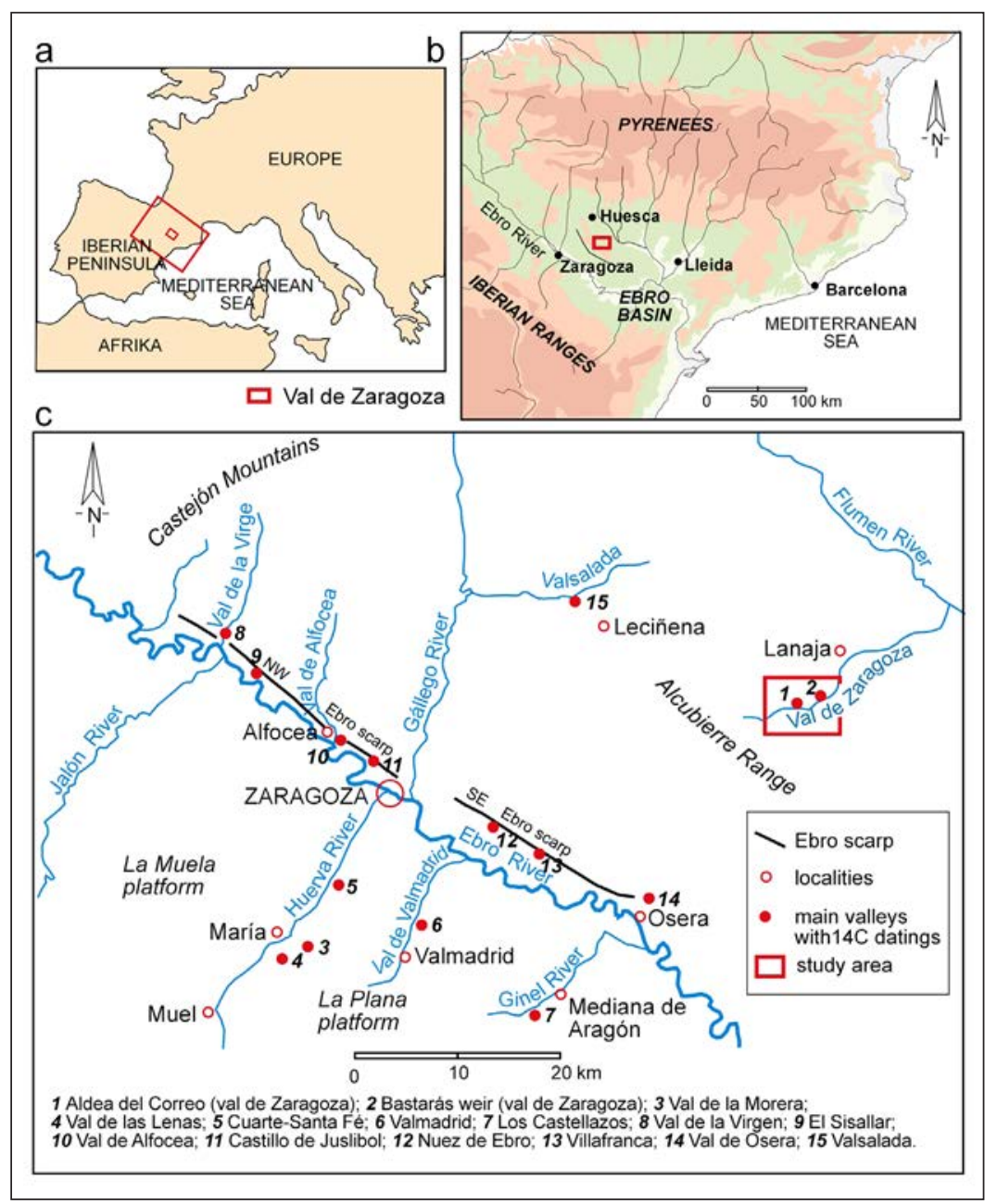

Figure 1.a) General location map; b) Location map of the main dated valleys and archaeological remains of the Ebro basin. Location of Val de Zaragoza in the regional context. 
There is no synthesis that covers this geographical area in a single evolutionary model so far. In this study, the Val of Zaragoza, a secondary valley located to the north of Los Monegros, to the NE of Zaragoza city, provides an example and analog to synthesize the evolution and processes involved in the development of flat-bottom valleys. Besides, its geological substrate (limestones and marls) different from that previously described (basically gypsum), it is also higher than average, has north orientation and higher than average humidity in the central Ebro basin (average annual precipitation of about 400-450 mm against 300-350 mm) give a completely different microenvironment and offers new data about the climatic influence on the evolution of Holocene valleys. Moreover, the existence of a remarkable weir for irrigation in the middle section of the valley, built during the 19th century, enabled establishing its relationship with the wetter climatic periods of the LIA. In addition, we analyzed the influence human interference in the geomorphological dynamics of the valley and the responses in terms of aggradational and erosive processes.

\section{Study area}

The Val of Zaragoza is in the north of the Ebro Tertiary Depression, in the Los Monegros area, and close to Lanaja (Huesca Province, Spain) (Fig. 1c). The topography of Los Monegros is dominated by the Lanaja and Alcubierre Ranges (832 m at San Caprasio Mount) (Fig. 2), which form an elongated NW-SE oriented alignment. These ranges are the watershed limit between the southern slopes that directly flow to the Ebro River and the tributaries of the Flumen and Guatizalema rivers coming from the Pyrenean piedmont.

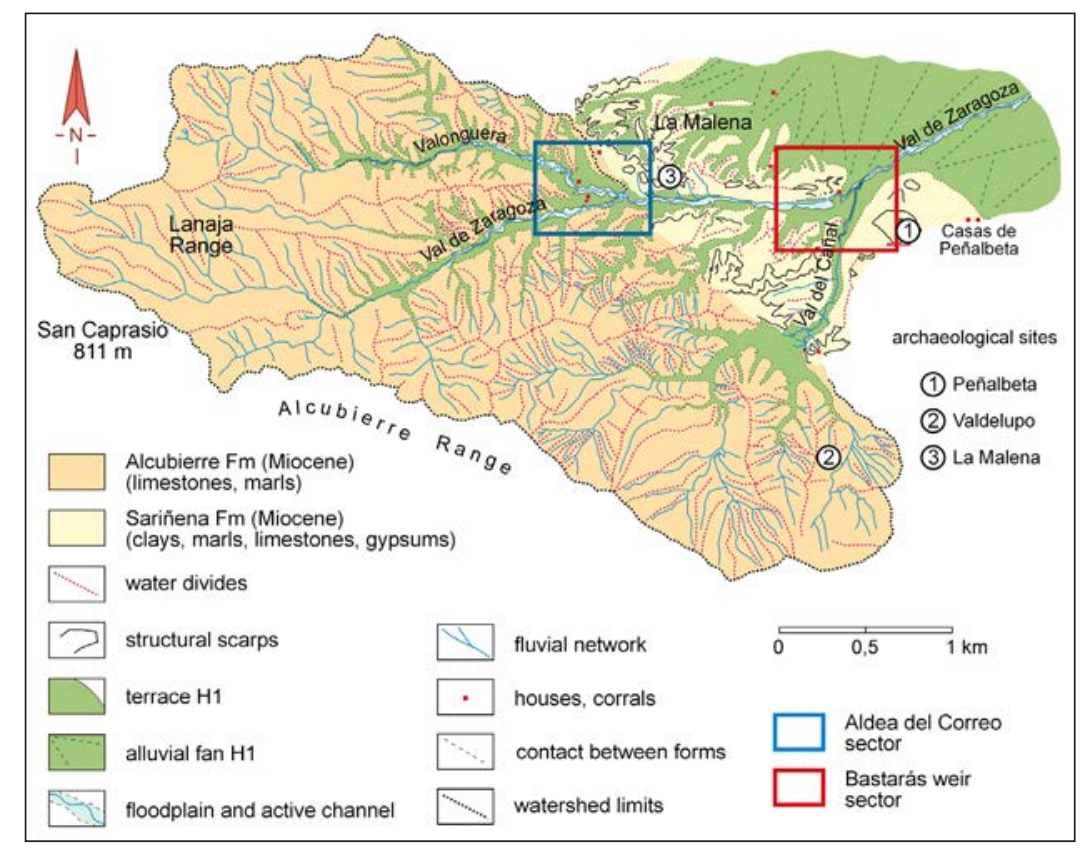

Figure 2. Geological and geomorphological map of the Val de Zaragoza basin, location of the detailed maps of the studied areas (Figs. 4 and 6). 
This section of the Ebro basin is composed of Miocene continental sediments from two geological units (Fig. 2): Sariñena Fm and Alcubierre Fm (Quirantes, 1978; Riba et al., 1983). Their chronostratigraphy correspond to the Aragonian and Vallesian stages (Costa et al., 1998). The units are part of the Tecto-sedimentary units T5 and T6 proposed by Alonso-Zarza et al. (2002). The Alcubierrre Fm emerges at the head and middle section of the Val de Zaragoza and it is composed of limestones and marllimestones. The Sariñena Fm consists of detrital materials, with a predominance of sandstones and marls and some interbedded limestones. In the final reach, the valley runs along a deep canyon excavated on dark gypsum deposits of Sariñena Fm.

These geological units have a sub-horizontal stratification and form narrow stepped platforms and mesas eroded by a dense incised drainage network. The headwaters of Val de Zaragoza, Valonguera and Val del Cañal are in the northern slope of Alcubierre and Lanaja Ranges, descending through their piedmont formed by one of the previously described platforms and some Pleistocene glacis remnants where Holocene valleys (or "vales") are entrenched (Fig. 3).

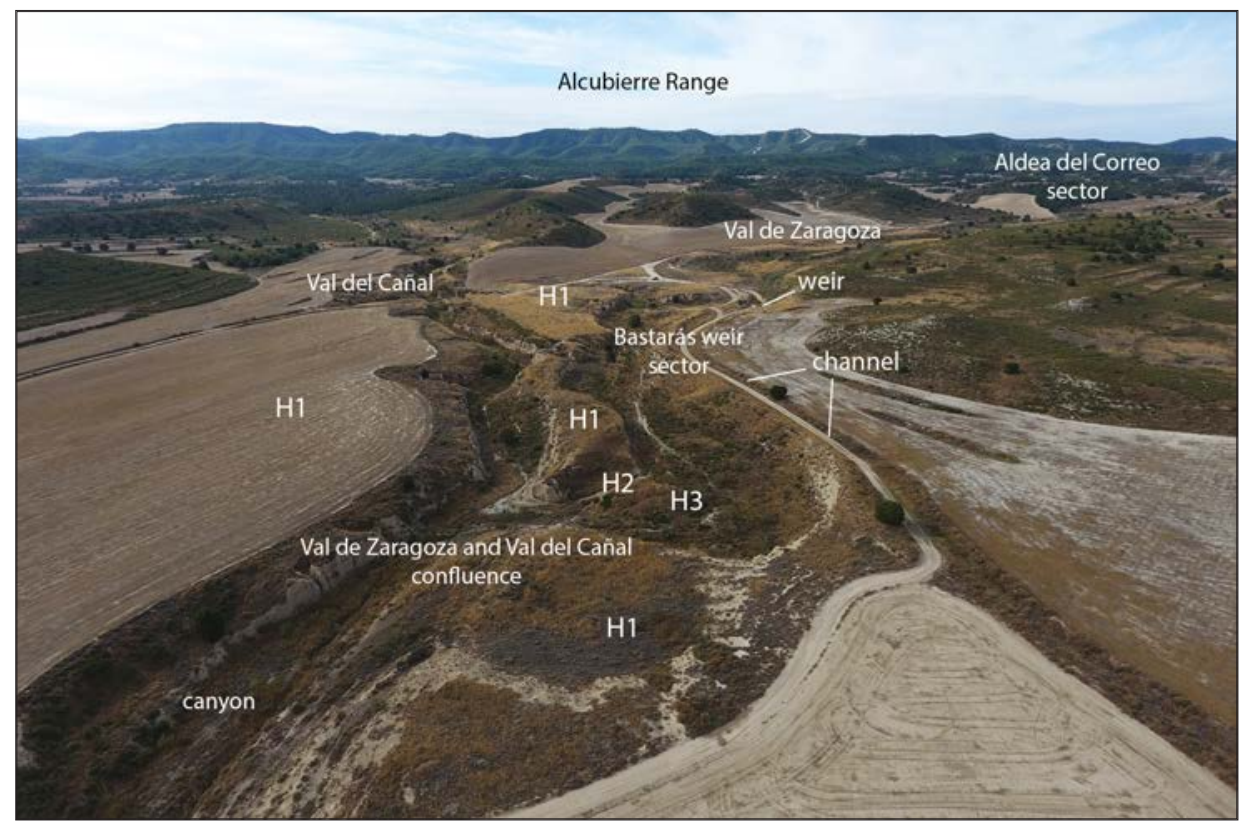

Figure 3. Aerial photograph of Val de Zaragoza from the Val del Cañal confluence looking the bottom the Alcubierre Range.

The Val de Zaragoza climate is continental Mediterranean with semiarid characteristics; annual average precipitations are between $400-450 \mathrm{~mm}$, falling in spring and autumn. Mean annual temperature is around $15^{\circ} \mathrm{C}$. Prevailing NW winds (cierzo) tend to dry the soils. The area has a major water deficit conditioning the development a poor plant coverage, and is also influenced by secular human impact. The structural reliefs are characterized by open forests 
of quejigos (Quercus faginea), holm oak (Quercus ilex), sabin juniper (Juniperus thurifera), and pine (Pinus halepensis), accompanied by scrubs; rosemary (Rosmarinusofficinalis), thyme (Thymus vulgaris), and sage (Salvia lavandulifolia). Valley bottom soils are rich in sodium, so albardín (Lygeumspartium) and tamarix (Tamarix africana and Tamarix gallica) are abundant near ephemeral water courses. Any irrigation channel (Monegros Channel) is close enough to permit irrigation agriculture in this part of the inner piedmont.

Vales belong to a type of ephemeral streams that are named ramblas or rieras in the Mediterranean region. Their main characteristic is that for most of the year they remain dry, with flows linked to sporadic rains. The current climate makes it difficult to believe that water one regularly flowed in these streams or vales. However, the presence of a weir at Val de Zaragoza indicates that the situation differed in the recent past. At some point, it was possible to retain and divert water for irrigation, which implies a higher precipitation regime in this area of the Ebro Depression.

From the perspective of human occupation, the temporal and spatial archaeological knowledge of Sierra de Alcubierre and Los Monegros area is not homogeneous. Some extensive surveys showed significant occupation from the Neolithic to the Roman Epoch, and so, the landscape was under a strong and continuous human pressure. Several archaeological sites with differing chronologies are known around the Val de Zaragoza (Domínguez et al., 1984; Giral Royo, 2014) (Fig. 2) and these include Peñalbeta with Neolithic remains, Valdelupo belonging to the Final Bronze-Iron I, and La Malena, the most important settlement in the area. The occupation of La Malena dates back to the Iron Age, with important settlements from the Iberian Epoch, Roman Republic and Imperial Roman Periods, covering the 5th century BC to the 5th century AD. A set of Iberian and Roman coins was found in this settlement. The presence of these archaeological sites at the Val de Zaragoza could be related, as evidenced by its name, to the fact that it was the natural route for traversing the ranges from Zaragoza city to the piedmont of the Alcubierre Ranges. The Aldea del Correo (Post Village) served the communications of the Camino Real (King's Road).

\section{Methodology}

A geomorphological map of the Val de Zaragoza basin was made, as well as two detailed maps of the areas with the most relevant Holocene accumulations. The main reliefs and Holocene sedimentary records are represented on this map, following the methodology proposed by Peña Monné (1997) for geomorphological cartography, and another more recent bibliography (Peña Monné et al., 2004; Peña Monné et al., 2014). The cartography was made using topographic maps $(1: 25,000)$ of Instituto Geográfico Nacional (Spain), aerial photographs of the Interministerial Flight from Spain $(1: 18,000)$, orthoimages from Servicio de Información Territorial de Aragón (2012), and images from Google Earth (2013). The longitudinal and transversal profiles of the valley and their accumulation levels were made using the GPSs Trimble Geoexplorer GNSS and Garmin Montana 650. 
Intensive surveys were made on the Holocene accumulations and surrounding areas. These accumulations are typologically classified by their relative chronological value and the intensity of the human impact on the area. Moreover, several charcoal samples were taken for radiometric dating at Beta Analytic (Miami, USA), Arizona University (USA), and Direct AMS (USA). Radiocarbon datings were calibrated using Oxcal 4.2 software with the INTCAL13 curve, considering one sigma. In addition, the datings from the Val de Zaragoza were compared with those of other valleys in the central Ebro basin using the same calibration criteria. However, in the final representation, the middle point of each calibration BP was considered.

The wood charcoal analysis was made at Departamento de Ciencias de la Antigüedad, at the University of Zaragoza. A metallographic dark/bright field incidentlight microscope (Leica DM2700M) with magnification factors of 100 to 630x was used. Photographs were taken with a coupled digital camera using LAS V4.10 software. The study followed the standardized anthracological methodology (Vernet, 1973). Each fragment was manually broken and the anatomical patterns of each wood species were observed along three anatomical sections: transversal (ST), radial longitudinal (SLR), and tangential longitudinal (SLT). Botanical identification was possible by referencing wood anatomy atlases for both non-charred (Schweingruber, 1990; Garcia Esteban et al., 2003) and charred wood (Vernet et al., 2001), together with the laboratory reference collection.

\section{Results}

The headwaters of the Val de Zaragoza basin is located at the top of Alcubierre, Range the highest point being the summit at Mount San Caprasio (832 m). This area, known as Lanaja Range, has developed a relief compartmentalized by the river network with narrow ridges of Miocene limestones (Fig. 2). The drainage is W-E, with two main sections: Val de Zaragoza proper and Valonguera, which converge in the middle course at Aldea del Correo reach, where extensive deposits are observed (Fig. 2). The drainage system presents a rectilinear layout, oriented in a W-E direction, at the foot of La Malena reliefs, where it receives tributaries from small southerly basins. This channel converges with the Val del Cañal (Figs. 2, 3) at the Bastarás weir. From this point downwards, the val is incised on coalescent alluvial fans (Fig. 2). A deep incision characterizes the lower section of the river, from Bastarás weir up to Lanaja, Finally, the val converges with the Flumen River 12 km downstream.

Most of the valleys have infilled flat bottom morphologies due to slope degradation processes. A later incision affected part of their fill, producing a narrow entrenchment of vertical walls and slightly sinuous channels, with meanders in some places (Fig. 3). The incision was formed by piping processes, which favored the headward erosion upstream and laterally with small arched headwaters or amphitheaters due to sediment collapses. This process was accelerated by sediment sodicity, which potentiated circulation and pipe formation hypodermically. As in the other vales analyzed, the incisions evolved with lateral collapses enhanced by undermining of the val margins (Peña Monné, 1996; Peña Monné et al., 2004). 
Later recurrent aggradation and downcutting periods developed lower terraces that are only identifiable in the less eroded sections. This sequence of stepped alluvial surfaces was also identified in other vales of the Ebro basin by the latter authors. They are known as level N3 (the main and oldest level), and N2 and N1 (the most recent ones). In some areas, it is possible to find a NO level in an even lower position, close to the river thalweg (Peña Monné et al., 2004). In this work, these levels are named H1, H2, H3, and H4, i.e., numbered from the oldest to the most recent. These terraces are connected with slope deposits towards the val margins. The morphology is differentiated into terraces $(t)$ or slopes (s), as they appear in the profiles and maps in this paper.

The confluences of the Valonguera (Aldea del Correo sector) and Val del Cañal (Bastarás weir sector) into the Val of Zaragoza hold the thickest Holocene accumulations and represent the most interesting reaches (Figs. 2,3): The following descriptions focus on these two points.

\subsection{Aldea del Correo sector}

The area of confluence between Val de Zaragoza and Valonguera is one of the widest reaches with Holocene accumulations, as shown in the geomorphological map (Fig. 4). The main level (H1) forms large and wide fluvial terraces at both margins and its deposit reaches $8 \mathrm{~m}$ in thickness, offering a complete sedimentary sequence.

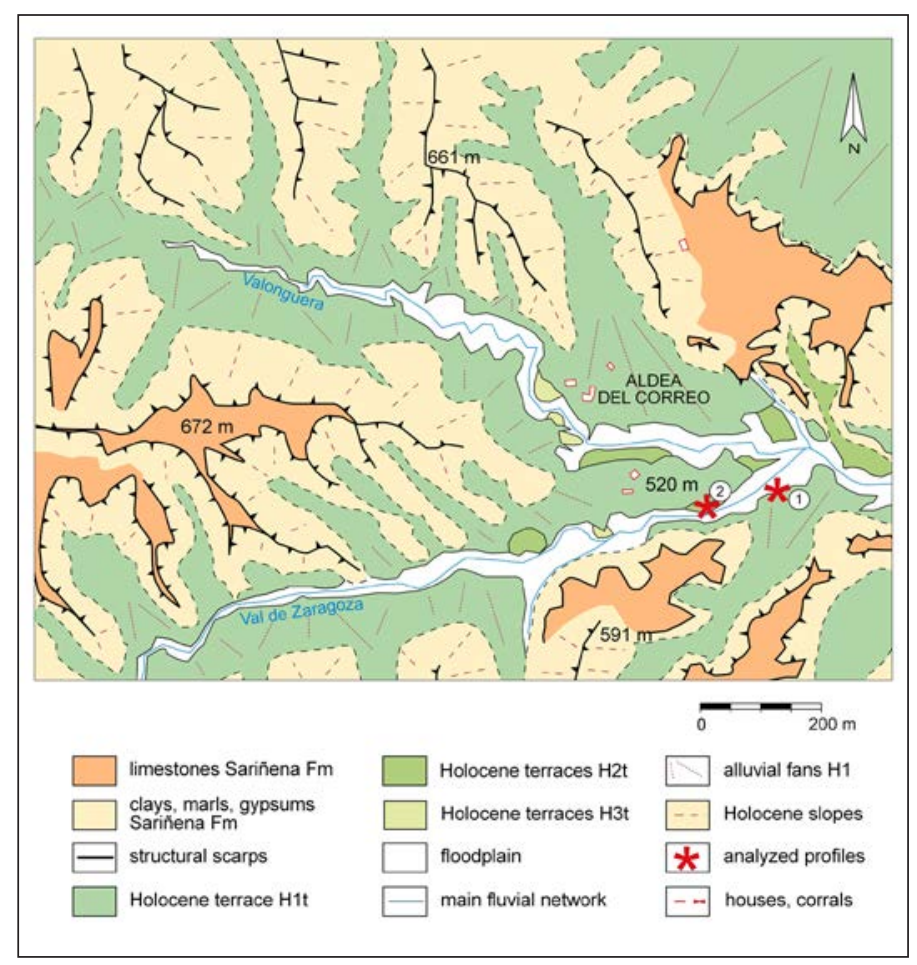

Figure 4. Geomorphological map of Aldea del Correo sector. 
Figs. 5a and 5b show the 8,35 m thick stratigraphic profile of the $\mathrm{H} 1$ terrace deposit at point 1 in Fig. 1c, and located on the left margin of Val de Zaragoza. The profile is a relatively homogeneous detrital series composed of two main sequences. The lower one is composed of limestone gravels at the base (A), followed by a $2.3 \mathrm{~m}$ layer of sands and clays with some interbedded gravels (B) and a paleosoil (C) (Fig. 5a). A charcoal sample (VALCO-3, Table 1) was taken from this paleosoil and dated at $4090 \pm 29{ }^{14} \mathrm{C}$ yr BP (4785-4526 cal yr BP). The upper sequence is made up of $3 \mathrm{~m}$ thick sand and clay unit (D) with similar sedimentological characteristics as unit B. It is overlaid by a $2 \mathrm{~m}$ thick unit (E) of gravel beds with some calcareous blocks and interbedded channel structures that evidence an intense and dynamic activity in this upper sequence. From a morphological point of view, gravel channels are competent beds that resist erosion and develop ledges while sand and clay beds form cavities and chimneys due to piping and surface runoff processes (Fig. 5b).

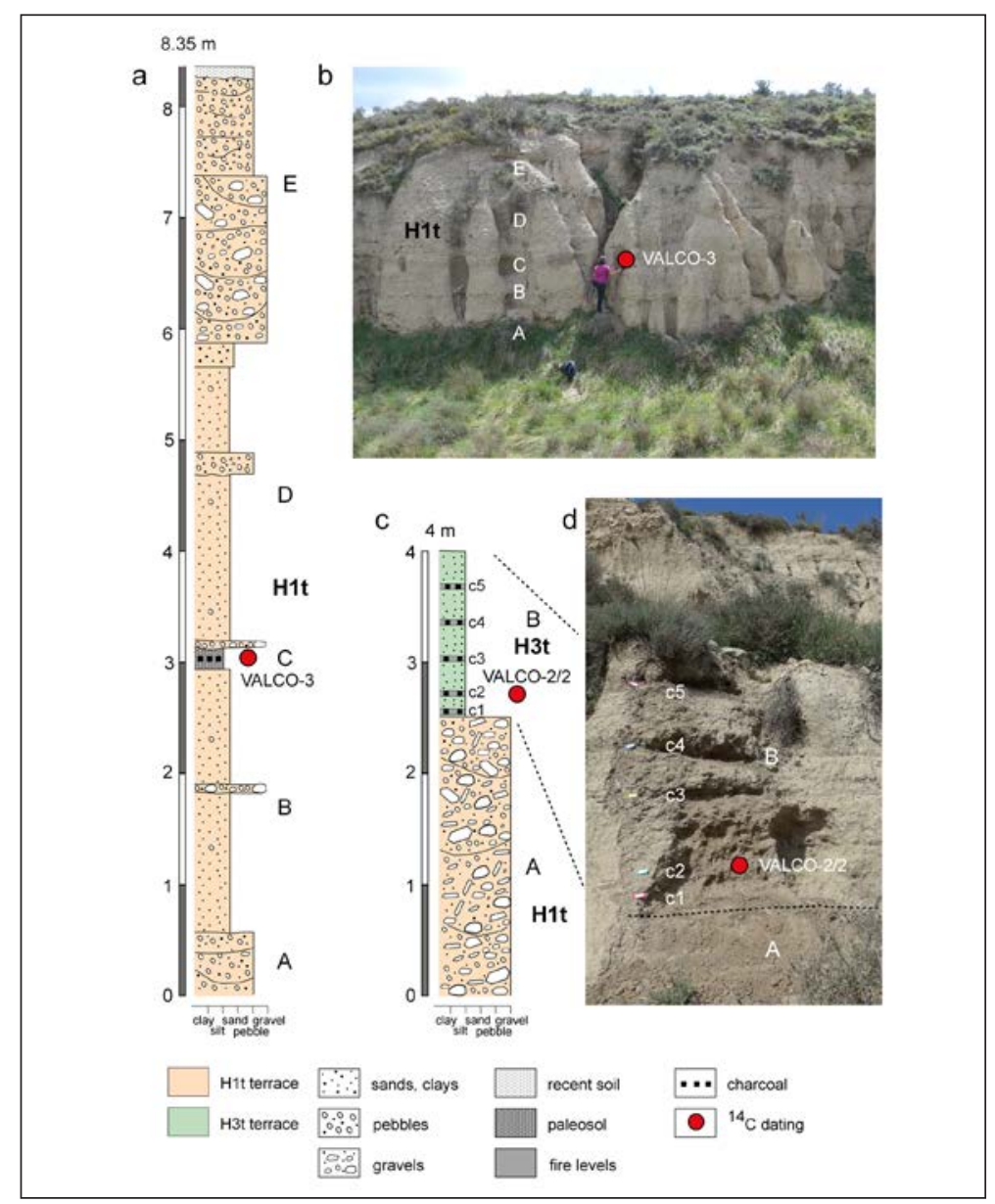

Figure 5. Stratigraphical profiles of Aldea del Correo sector: a) profile and b) photograph of the $\mathrm{HI}$ terrace; c) profile and d) photograph of the H1-H3 terrace fills. 
Table 1. Radiocarbon datings.

\begin{tabular}{|c|c|c|c|c|c|c|}
\hline Field code & $\begin{array}{c}\text { Laboratory } \\
\text { reference }\end{array}$ & Material & ${ }^{14} \mathrm{C}$ yr BP & Cal yr BP & $\begin{array}{c}\text { Cal yr BC/AD } \\
\text { (2 o ranges) }\end{array}$ & $\begin{array}{c}\text { Cultural } \\
\text { period }\end{array}$ \\
\hline VZ-06 & $\begin{array}{l}\text { BETA- } \\
347452\end{array}$ & Charcoal & $4160 \pm 30$ & $\begin{array}{l}1 \sigma: 4821-4628 \\
2 \sigma: 4829-4581\end{array}$ & 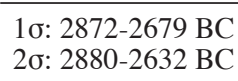 & $\begin{array}{l}\text { Bronze } \\
\text { Age }\end{array}$ \\
\hline VZ-04 & $\begin{array}{l}\text { AA108298 } \\
\text { X29002 }\end{array}$ & Charcoal & $4153 \pm 30$ & $\begin{array}{l}1 \sigma: 4820-4621 \\
2 \sigma: 4826-4580\end{array}$ & 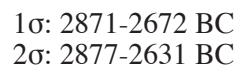 & $\begin{array}{l}\text { Bronze } \\
\text { Age }\end{array}$ \\
\hline VZ-02 & $\begin{array}{l}\text { BETA- } \\
347451\end{array}$ & Charcoal & $1970 \pm 30$ & $\begin{array}{l}\text { 1б: } 1948-1882 \\
2 \sigma: 1994-1865\end{array}$ & $\begin{array}{c}\text { 1б: } 2-68 \mathrm{AD} \\
2 \sigma: 45 \mathrm{BC}-85 \mathrm{AD}\end{array}$ & $\begin{array}{l}\text { Roman } \\
\text { Period }\end{array}$ \\
\hline VALCO-3 & $\begin{array}{l}\text { D-AMS } \\
010947\end{array}$ & Charcoal & $4090 \pm 29$ & $\begin{array}{l}1 \sigma: 4785-4526 \\
2 \sigma: 4808-4449\end{array}$ & $\begin{array}{l}\text { 1б: } 2836-2577 \mathrm{BC} \\
2 \sigma: 2859-2500 \mathrm{BC}\end{array}$ & $\begin{array}{l}\text { Bronze } \\
\text { Age }\end{array}$ \\
\hline VALCO-2/2 & $\begin{array}{l}\text { D-AMS } \\
010948\end{array}$ & Charcoal & $\begin{array}{c}100.16 \pm \\
0.36\end{array}$ & $\begin{array}{l}1 \sigma: 251-35 \\
2 \sigma: 254-32\end{array}$ & $\begin{array}{l}1 \sigma: 1699-1915 \\
2 \sigma: 1696-1919\end{array}$ & LIA \\
\hline
\end{tabular}

Radiocarbon ages were calibrated to 'calendar' ages by using Oxcal v4.2.4 Bronk Ramsey (2013); IntCal13 atmospheric curve (Reimer et al., 2013).

On the right margin of the same incision, $\mathrm{H} 3 \mathrm{t}$ and $\mathrm{H} 2 \mathrm{t}$ are preserved forming discordant steps unconformably lying on 2,4 m thick channel gravels belonging to H1t (Figs. 4 and 5c, unit A). In one of the outcrops (point 2, Fig. 4), H3t deposits consist of $1.5 \mathrm{~m}$ thick alternating sandyclay and highly carboniferous layers (c1 to $\mathrm{c5}$ ) (Figs. 5c, d). These carboniferous layers seem to be composed of materials eroded from nearby areas that burned periodically. A recent radiocarbon date of 251$35 \mathrm{cal}$ yr BP was obtained from layer c2. Despite the lack of precision of this dating, this accumulation is clearly related to the Little Ice Age.

Samples from carboniferous c1 to c5 were taken for anthracological study and only the oldest one (c1) was sterile. A total of 175 charcoal fragments from layers c2 to c5 were analyzed, among which at least six taxa were documented (Table 2). The entire sequence is dominated by the presence of Aleppo pine (Pinus halepensis). It was not possible to observe all the necessary features in all the fragments due to their small size or poor state of conservation. Therefore, different determination levels were established: Pinus sp., Pinus cf. halepensis, Pinus halepensis/pinaster and even undetermined conifers. All of these fragments probably belong to this taxon and $P$. halepensis is also the only clearly determined conifer in the record. In c5 it was possible to only identify $P$. halepensis while in the other layers this conifer is accompanied by other less representative taxa. Evergreen oaks and helm oaks (Quercus coccifera/ilex, respectively) are present at all layers except c5, were Aleppo pine is the only identified taxon. Other less climate representative taxa, such as Rosaceae (c2 and c4) and probably the genus Pistacia (cf. Pistacia sp.) (c3), were also documented. The record points to an open Mediterranean landscape similar to the modern landscape. The presence of two deciduous oak fragments (Quercus sp. deciduous) in the c4 layer is remarkable, and reveals high taxonomic variability and is possible evidence of some environmental humidity. 
Table 2. Results of charcoal analyses.

\begin{tabular}{lcccc} 
Level & $\mathbf{c 5}$ & $\mathbf{c 4}$ & $\mathbf{c 3}$ & $\mathbf{c 2}$ \\
Depth $(\mathbf{c m})$ & $\mathbf{3 0}$ & $\mathbf{6 6}$ & $\mathbf{9 1}$ & $\mathbf{1 3 0}$ \\
\hline Bark & 1 & 2 & 5 & 3 \\
Indeterminable conifer & - & - & 1 & 1 \\
Pinus halepensis & 49 & 38 & 33 & 16 \\
Pinus cf. halepensis & - & - & 3 & - \\
Pinus halepensis/pinaster & - & - & 1 & - \\
Pinus sp. & - & 4 & 4 & 3 \\
cf. Pistacia sp. & - & - & 2 & - \\
Rosaceae Prunoideae & - & 1 & - & - \\
Quercus coccifera/ilex & - & 1 & 1 & 1 \\
Quercus sp. deciduous & - & 2 & - & - \\
Rosaceae Maloideae & - & 2 & - & - \\
cf. Rosaceae Maloideae & - & - & - & 1 \\
\hline
\end{tabular}

From the taphonomic point of view, the size of the charcoals varied from small branches $(2 \mathrm{~mm}$ ) with cambium and bark to large fragments of weakly curved growth rings suggesting that they come from big branches and trunks. All samples showed bark and several fragments are affected by vitrification.

\subsection{Bastarás weir sector}

This area that also shows extended Holocene deposits, is located in the lower meandering reach of Val de Zaragoza at the confluence with Val del Cañal. The infilling deposits are deeply incised leading to a narrow canyon downstream to Bastarás weir (Figs. $3,6 a)$. The dynamics and recent evolution of this stream reach was strongly controlled by the construction of a weir and other irrigation works (levees, canals, water breakers, and walls) at the beginning of the19th century (Fig. 6a).

The Bastarás weir was built to retain and redirect the sporadic flow waters of the Val de Zaragoza stream for the irrigation of the lands of the Bastarás property, near Lanaja. The weir caused the retention of a large amount of sediment following its construction, favoring aggradation upstream of the dam, and the erosion of the channel deposits downstream generating a canyon that reaches the bedrock. This phenomenon distorted the basal level of the stream channel on both sides of the weir, which must be considered when analyzing terrace surfaces profiles. Similarly, the meander located upstream of the weir was modified by the construction of slightly oblique earth levees on the right margin to direct the flow to the weir (Fig. 6a). For this reason, erosion has focused on the left margin giving way to prominent scarps. The geomorphological cartography (Fig. 6a) enables identifying three stages present at Aldea del Correo area ( $\mathrm{H} 1$ to $\mathrm{H} 3$ ), with stage $\mathrm{H} 1$ being much more extensive than 
the others. Moreover, the Val de Zaragoza longitudinal profile (Fig. 6b) shows the general continuity of $\mathrm{H} 1$ level, with an average gradient of $18.3 \%$, the discontinued presence of levels $\mathrm{H} 3$ and $\mathrm{H} 2$, and the stream gradient rupture that the weir generates. The location of the four studied profiles described below is shown with numbered asterisks in Figs. 6a, b.

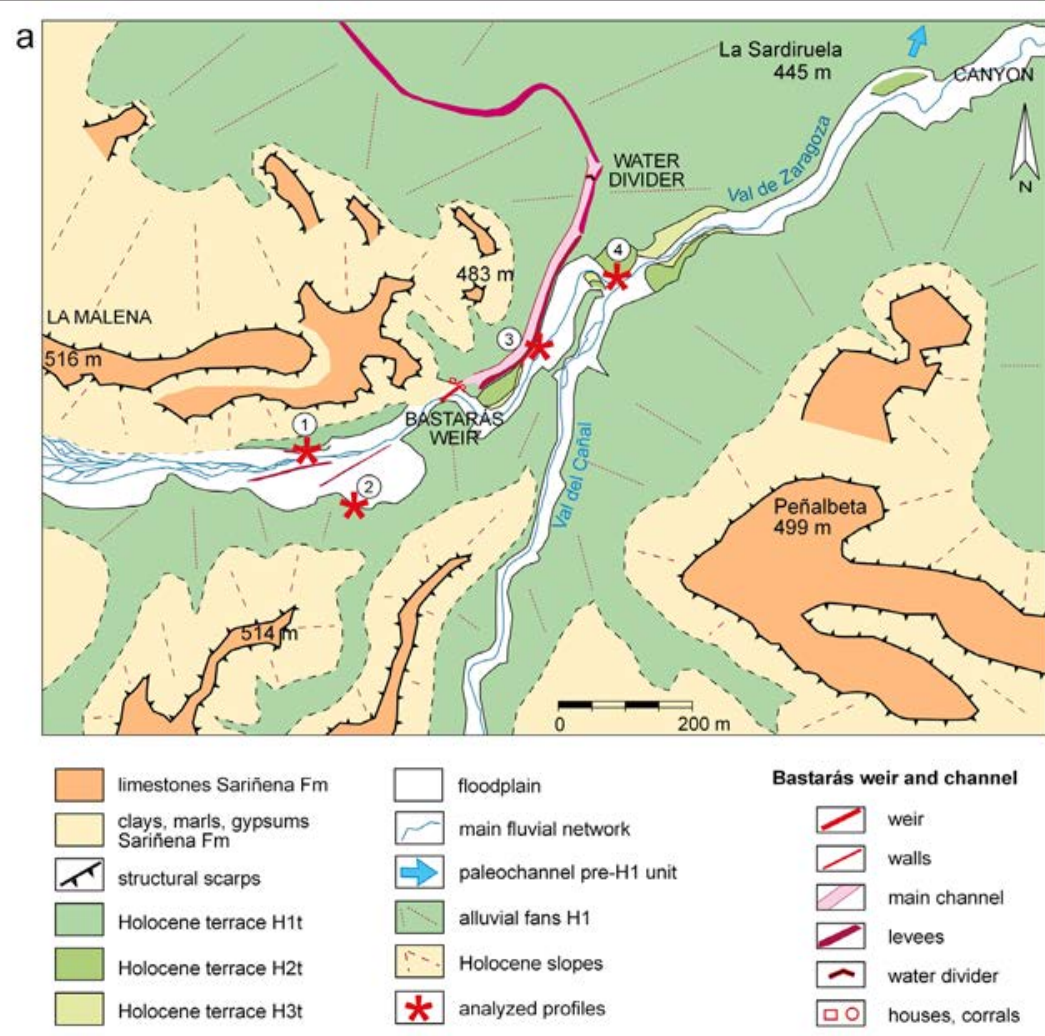

b

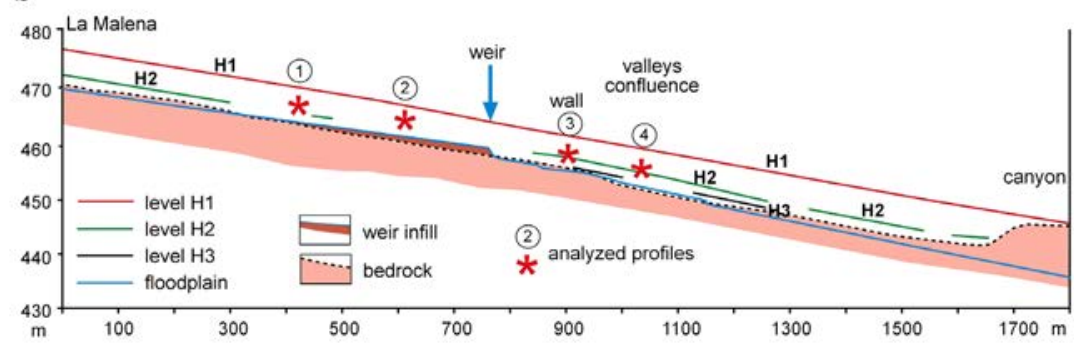

Figure 6. a) Geomorphological map of the Bastarás weir sector; b) longitudinal profile of Holocene levels $\mathrm{H3}, \mathrm{H} 2$, and $\mathrm{H1}$, with the situation of the four profiles analyzed in the weir of Bastarás sector. The infill and incision induced by the weir is indicated. 
Upstream of the weir, two long outcrops are exposed on both margins of the river course (Fig. 7), without reach the bedrock, showing the complete H1 sequence, as well as the sedimentary and morphological characteristics of stage H2. On the left margin, profile number 1 (Figs. 6a, b) is located in a $150 \mathrm{~m}$ long stream scarp that displays 2,6 m thick $\mathrm{H} 1$ deposit unconformably overlying by $0,4 \mathrm{~m}$ thick $\mathrm{H} 2$ terrace fill (Figs. 7a, b), without reaching the Miocene substrate. Form base to top, It is possible to identify the following units: (1) Unit A is made up of limestone gravel channels, with some interbedded sandy layers, $1 \mathrm{~m}$ thick accumulation of sand and clay, and $0.5 \mathrm{~m}$ of channel gravel facies. A charcoal sampled at the base of the profile taken from a sand layer was dated at 4821-4628 cal yr BP (VZ-06, Table 1); (2) The next section (B), is $10-20 \mathrm{~cm}$ thick and an almost continuous dark layer composed of sediments carried from upslope, containing numerous fragments of charcoal and ashes (unit B), that was also observed on the right margin of the stream with much more continuity; (3) $0.8 \mathrm{~m}$ of sandy clay sediments with dispersed limestone gravels (unit $\mathrm{C}$ ) that are truncated by $0.9-1 \mathrm{~m}$ thick $\mathrm{H} 2$ deposits. The slope sediment developed at the foot of the nearby structural reliefs, mainly comprises fine sediments and ceramic fragments of different times (Roman, Medieval). This postmedieval times sediment covers the surface of almost the entire H1 unit. Further north, unit $\mathrm{H} 2 \mathrm{~s}$ becomes thicker and descends to laterally link and overlie H2t (Figs. $7 \mathrm{a}, \mathrm{c})$. This last unit is composed in this sector of limestone blocks and gravels, which are badly stratified and little rounded, with almost no imbrication.

The second outcrop (number 2, Figs. 6a, b) is located in a $200 \mathrm{~m}$ long meander scarp on the right margin of the Val de Zaragoza behind the earth levees used to divert the waterflow to the Bastarás weir (Fig. 7d). Six profiles were described but only the most representative one was selected for this paper (Fig. 7e). The profile consists of $2.35 \mathrm{~m}$ thick, compacted sandy loam sediments, with columnar shape especially in the lower section and partly related to piping and rilling processes (units A and C) with an interbedded 10-20 cm dark layer (unit B), also formed by ashy materials from burned vegetation. This sedimentary package ends with a thin gravel bed that, gives rise to a gravel pavement with biological crust and whose matrix is highly affected by the water erosion and aeolian deflation. The profile presents a large number of archaeological materials, especially in unit A (Fig. 7e). Most of them belong to the Imperial Roman phase coming from La Malena archaeological site (1st-5th centuries AD), and Iberian and Roman fragments with black varnish from the 2 nd or 1 st centuries BC. The most abundant fragments are of latter Terra sigillata from Spain and Africa. Metallic objects were also found, such as a fragment of lead, probably related to a hydraulic structure of La Malena, and a bronze As of Domitian coin, struck in Rome in 85 AD, classified as RIC II 297 (C) (Mattingly and Sydenham, 1968).

The whole profile has abundant charcoal fragments, especially a layer located 25$30 \mathrm{~cm}$ below unit $\mathrm{B}$, where Roman potsherds were also observed. The layer was dated to $1948-1882$ cal yr BP) (VZ-02, Table 1) and is chronologically coherent with the coin and ceramic fragments. 


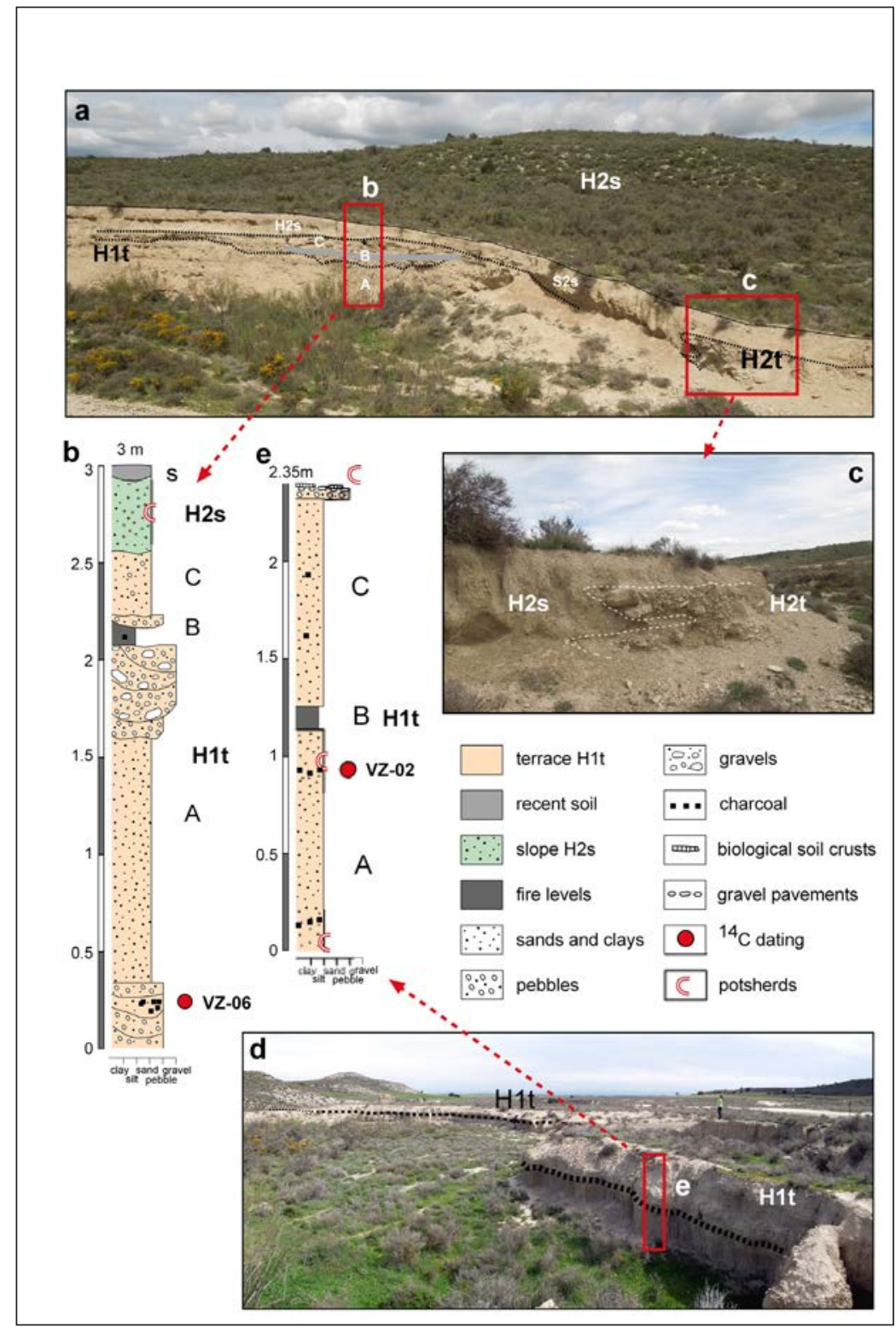

Figure 7. Stratigraphical profiles of Azud de Bastarás sector: a) general view of the outcrop on the left margin of the valley with the position of the analysed profiles ( $b$ and $c) ; d)$ view of the outcrop on the right margin of the meander; e) location of the analysed profile.

In the Bastarás weir and its channel, the levels pointed upstream are present. The stone walls that led to the channel reinforce the front of $\mathrm{H} 1$ level, and two small houses used for managing the weir were built above this accumulative level (Fig. 8a). The weir 
that was constructed in a $90^{\circ}$ meander turn, was built out of sandstone vertical blocks on which some iron rails were placed to be used as guides for wooden planks to close the water flow (Lasaosa, 1997) (Fig. 6). The channel was excavated at H1 level, which in this section reaches over $4 \mathrm{~m}$ in width. It was reinforced with an earth levee on its right margin by accumulating the excavated materials (Fig. 8b). This levee was necessary to protect the artificial channel from the eventual erosion and migration of the Val de Zaragoza (Fig. 6).

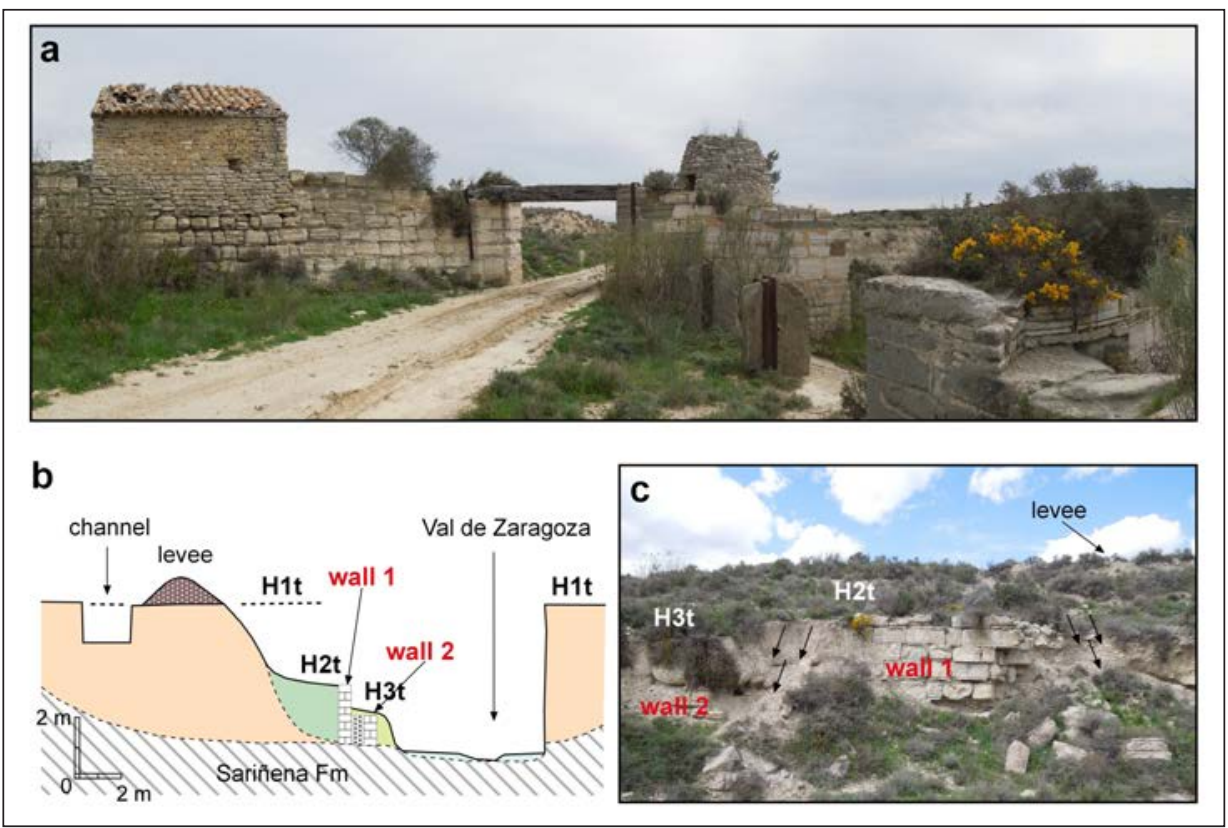

Figure 8. a) General view of the Bastarás weir and the channel begining; $b$ ) H1 accumulation with channel position, the lateral levee, and the fence walls (walls 1 and 2) related to $\mathrm{H} 2$ and $\mathrm{H} 3$ levels; c) detail of the wall position and location of $\mathrm{H} 2$ and $\mathrm{H} 3$ accumulations.

The dammed basin only included the Val de Zaragoza stream and its tributary, the Valonguera $\left(16.84 \mathrm{~km}^{2}\right.$ ), and exclude Val del Cañal (8.21 km²) (Fig. 9). Before it reaches the weir the main channel is $8.72 \mathrm{~km}$ long, with a slightly sinuous layout (index of 1.07 , according to the Morisawa (1985) classification). The drainage network consists of 583 channel segments reaching $125.8 \mathrm{~km}$ in total length. It has five orders according to the Strahler (1964) method, with bifurcation rate values of between 3 and 7.66, and showing an adequate hierarchy that favors the drainage of the area. Its density is $7.47 \mathrm{~km} / \mathrm{km}^{2}$, indicating a medium texture (Gregory and Walling (1973) classification). These values, together with the elongated shape of the basin and its strong gradient (between 811 and $460 \mathrm{~m}, 4.2 \%$ ), favor a fast flow transmission through the weir during rainy periods. This was probably the why the site was selected for the construction.

The presence of the weir not only caused aggradation upstream of the construction, but also an increase in the stream gradient downstream. At present, the 
stream must abruptly descend 2-2.5 $\mathrm{m}$ at the weir, favoring an increased incision, which in this section reaches up to $5.5 \mathrm{~m}$ and cuts the Miocene substrate of Sariñena Fm lying under the $\mathrm{H} 1$ accumulation. At the foot of $\mathrm{H} 1$ there is a relic of the $\mathrm{H} 2$ terrace, attached to a stone defense wall (wall 1, Figs. 8b, c). This wall must have been built to protect the upper artificial channel from erosion, probably potentiated by the weir construction. This wall was reinforced by constructing a second one wall (wall 2) and filling the room between them with soft material (point 3 Figs. 6a, b; Figs. 8b, c). This fill is visible because some of the stones have fallen. The H3 terrace was sedimented on the second wall. These types of relationships enable us to infer chronological data for this set of human and natural landforms.

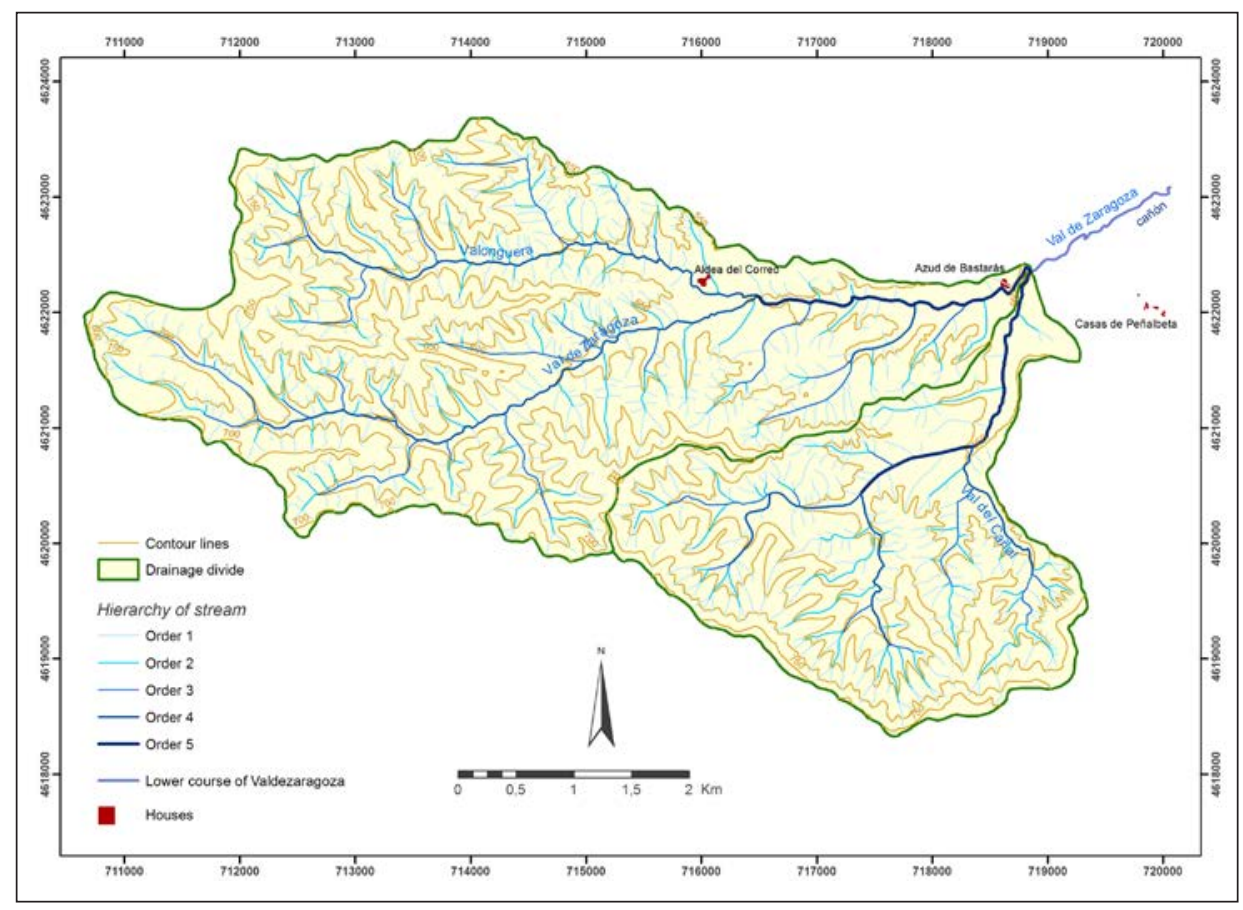

Figure 9. Drainage map of the Val de Zaragoza basin, closed by the Bastarás weir, with the main characteristics of the fluvial network.

At the confluence of the Val de Zaragoza and Val del Cañal streams (Figs. 3, 6), a narrow deposit of level H1t and several outcrops of levels $\mathrm{H} 3$ and $\mathrm{H} 2$ are conserved in a meander (Figs. 10a, b). On the right margin, there are three stepped units, with the development of an $\mathrm{H} 2 \mathrm{~s}$ slope deposit connecting the H1t scarp with the top of $\mathrm{H} 2 \mathrm{t}$ deposit. $\mathrm{H} 2$ is thin and overlaps $\mathrm{H} 1$. However, H3t forms an independent accumulation surface (Fig. 10b). This circumstance is repeated on the left margin of the stream, where a long H2s slope begins in the artificial channel levee area and forms a 2.5-m high scarp on the floodplain. However, most of the profile is composed of H1t deposit ( $2 \mathrm{~m}$ of the lower section) (Fig. 10c, point 4 in Figs. 6a, b), and only 
the upper $0.5 \mathrm{~m}$ belongs to $\mathrm{H} 2$. The lower section of $\mathrm{H} 1 \mathrm{t}$ is composed of silt and sand layers, with interbedded gravel channels, and three layers with abundant charcoal fragments. The section was dated at 4820-4621 cal yr BP (VZ-04, Table 1).

From its confluence with the Val del Cañal, the Val de Zaragoza stream begins to deepen in the alluvial cone of level H1, excavating a canyon in the Miocene substrate. In a profile at the beginning of the canyon it is possible to observe the original shape of the Val de Zaragoza during the formation of the H1 cone. The channel was NNE-oriented (Fig. 6a, upper left), while the present stream is NE-oriented on the cone margin. There are no accumulations in this area (Fig. 6b).

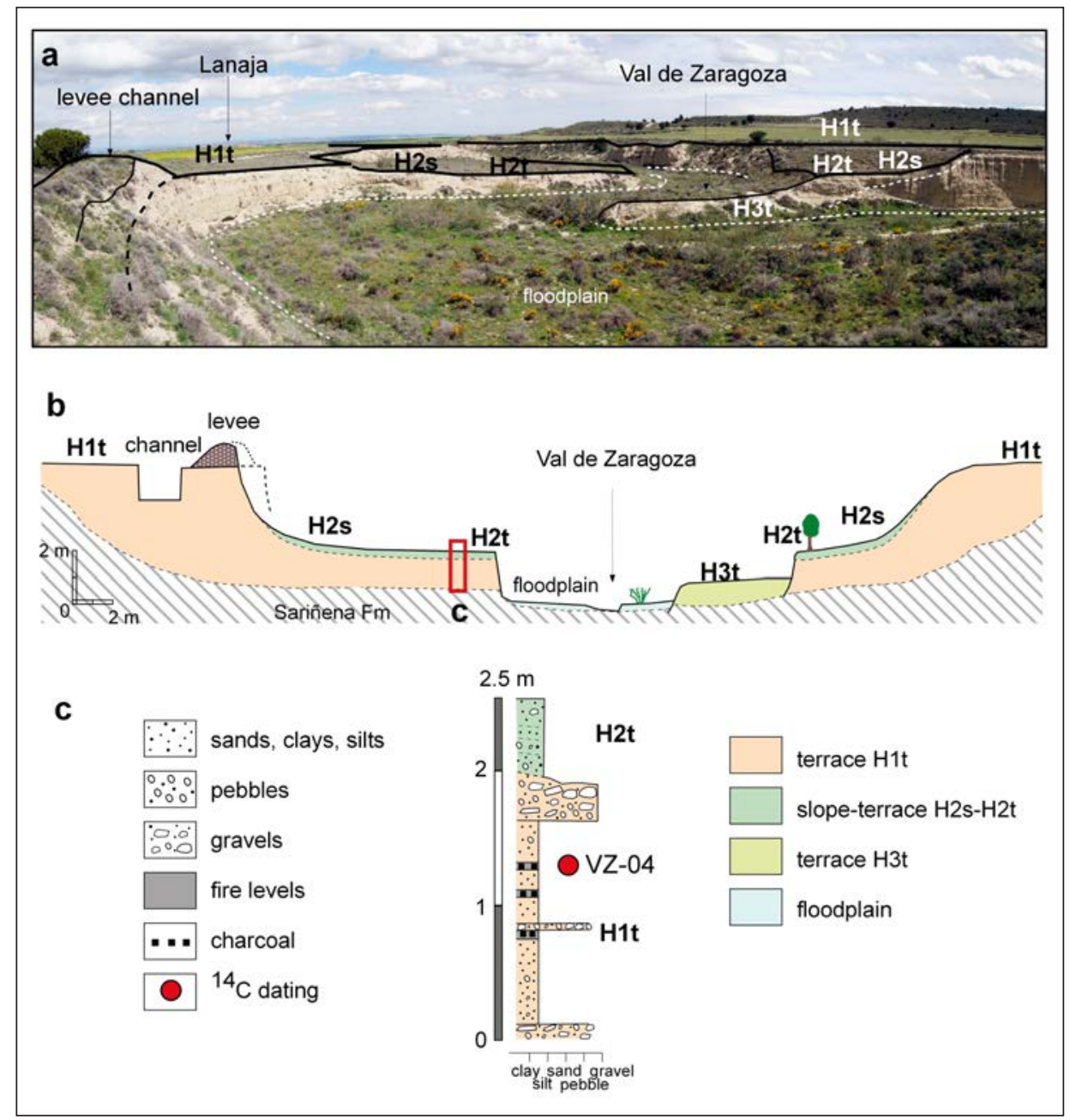

Figure 10. a) and b) transversal cross section of Val de Zaragoza in the meander close to the confluence with Val del Juncal; see the different accumulation levels and the position of the (c) stratigraphic profile. 


\section{Discussion}

The sequence of aggradational/degradational phases observed at the Val de Zaragoza shows an evolutionary process similar to other valleys in the Ebro basin. However, the South-North arrangement of Val de Zaragoza and its trajectory through non-gypsum substrate, makes this valley a very valuable case study. The two main accumulation surfaces are $\mathrm{H} 1$ and $\mathrm{H} 2$ units, whose geomorphological and chronological characteristics are contextualized within a regional framework to explore their paleoenvironmental meaning, relate them to the global Holocene data, and interpret the regional impacts of human activities.

\subsection{Accumulative stage H1: chronology and main features}

In the center of the Ebro basin (Figs. 1c, 11c, Table 3), the age of the H1 terrace is controversial although it seems its fill is the result of three overlapped aggradation phases. The oldest ages obtained for $\mathrm{H} 1$ aggradational stage correspond to Val de Osera (11396-11196 cal yr BP) (Arauzo and Gutiérrez, 1994), and Valsalada (1262812418 cal yr BP) (Sancho et al., 2007a). In Bardenas Reales de Navarra, in the center west of the basin, Peña Monné et al. (2006) and Sancho et al. (2007b, 2008) dated the oldest phase at 9380-7950 cal yr BP. This means that for the central part of the Ebro basin the first accumulation phase, hereby called H1A (Fig. 11f), occurred in the Early Holocene. A broader chronological group of dates, yields ages younger than $8200 \mathrm{BP}$ for the $\mathrm{H} 1$ deposits (Table 3). This is the case of the Huerva River, where Val de las Lenas was dated to 7154-6437 cal yr BP, Val de la Morera to 69496751 cal yr BP, and Cuarte to 4840-4627 cal yr BP (Peña Monné et al., 1993, 1998, 2001, 2004). In addition, Val de la Virgen, El Sisallar, and Alfocea, in the NW area of the Ebro scarp record (Fig.1c), were dated to 8033-7950 cal yr BP, 4965-4821 cal yr BP, and 4956-4709 cal yr BP, respectively. Similarly, Val de Nuez was dated to 5986-5756 cal yr BP and 5469-5318 cal yr BP (Constante et al., 2010, 2011). This set covers the Atlantic and Subboreal periods (Figs. 11a, b), and is culturally represented by the Neolithic and Chalcolithic (Fig. 11g). During those times, the regional climate was better for human occupation, and settlements resulted in thicker sedimentary records than in previous phases. The radiocarbon datings obtained in the lower sections of $\mathrm{H} 1$ from Val de Zaragoza belong to this chronological group. Datings are very similar: 4785-4526 cal yr BP at Aldea del Correo, 4821-4628 cal yr BP upstream of the weir, and 4820-4621 cal yr BP downstream (Fig. 11d). This wide initial phase, with variable beginning dates depending on the area, cover just one third of the $\mathrm{H} 1$ accumulation (the first 1-3 m of sediments, approximately) (Fig. 11e). This section reflects less human influence and so climate changes were probably the most important factor in its formation during the Early and Middle Holocene, as shown in Fig. 11b by the NGRIP curve (Rasmussen et al., 2007) and Bond events (Bond et al., 1997). However, data is too scarce to establish stronger connections with these environmental fluctuations. 


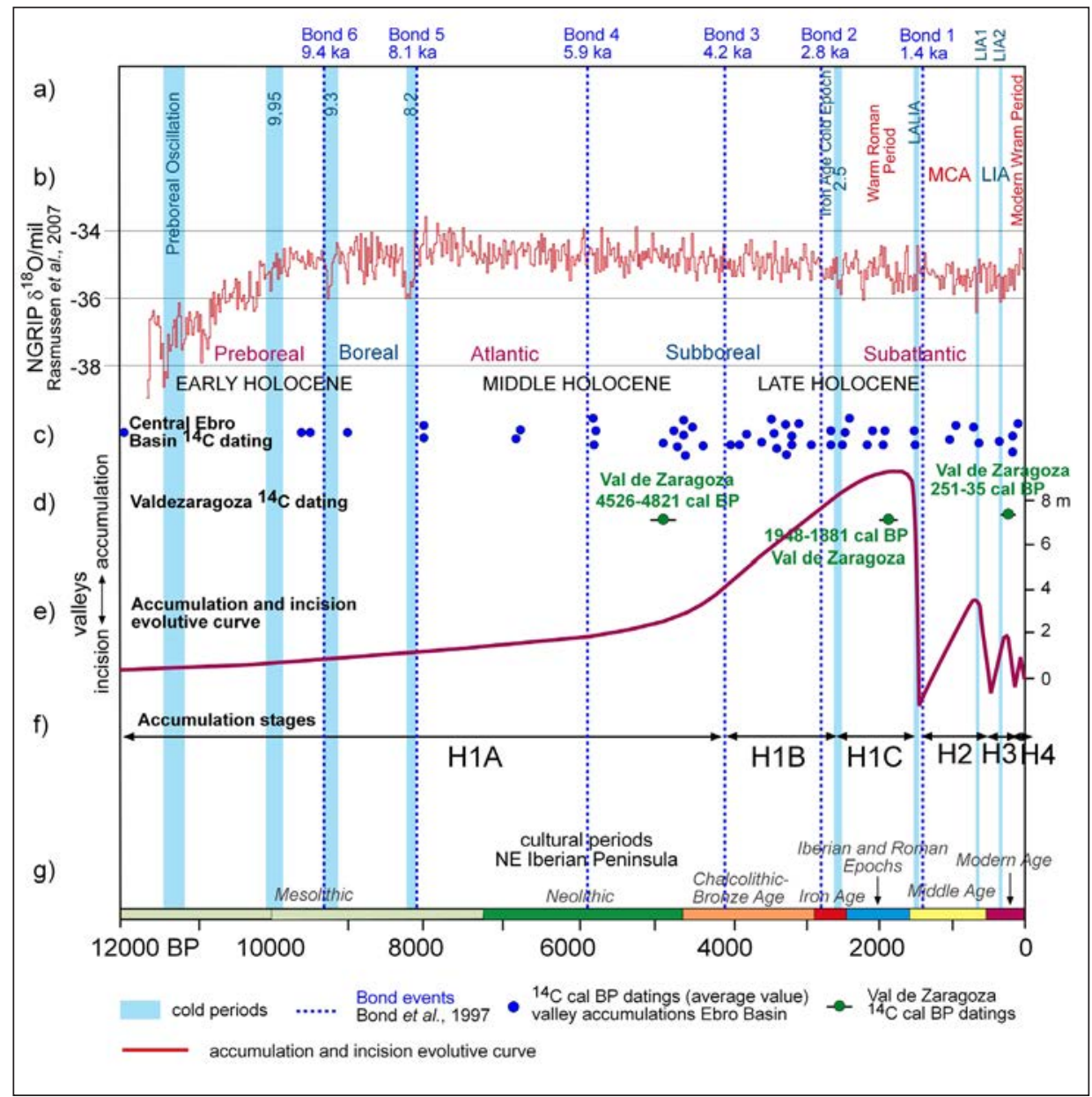

Figure 11. Paleoenvironmental and chronological information of the valleys of the central Ebro basin and the Val de Zaragoza on the Holocene environmental context: a) Chronological framework with the main Holocene climatic stages and Bond events (Bond et al., 1997); b) NGRIP curve (Rasmussen et al., 2007); c) calibrated radiocarbon datings from various valleys in the area (bibliographic references on the text); $d$ ) radiocarbon datings of the Val de Zaragoza; e) evolutionary curve proposed according to sedimentation and incision rates in the Ebro basin (expressed in $m$ approximately); $f$ ) Holocene accumulation stages identified; $g$ ) cultural periods from the NE of the Iberian Peninsula. 
Table 3. Main Holocene valley fills radiocarbon datings from the central sector of the Ebro Basin.

\begin{tabular}{|c|c|c|c|c|c|c|c|}
\hline $\begin{array}{c}\text { Sampled } \\
\text { valleys } \\
\text { and references } \\
(*)\end{array}$ & Age ${ }^{14} \mathrm{C}$ BP & Age Cal BP 1s & $\begin{array}{c}\text { Age cal BC/ } \\
\text { AD 1s }\end{array}$ & Unit & $\begin{array}{c}\text { Thickness } \\
\text { outcrop } \\
\text { (m) }\end{array}$ & $\begin{array}{l}\text { Depth of } \\
\text { sampling } \\
\text { (m) }\end{array}$ & $\begin{array}{c}\text { Aggradation } \\
\text { rate } \\
(\mathbf{m} / \mathbf{1 0 0 0} \text { yrs })\end{array}$ \\
\hline \multirow{3}{*}{$\begin{array}{l}\text { Val de la } \\
\text { Morera } \\
\text { (3) Peña Monné } \\
\text { et al., } 1998 \\
\end{array}$} & $6015 \pm 75$ & $6949-6751$ & $5000-4802 \mathrm{BC}$ & H1A & 10.2 & 9.8 & \multirow{3}{*}{ ] 1.5} \\
\hline & $3260 \pm 60$ & $3563-3410$ & $1614-1461$ ВC & H1B & 10.2 & 6 & \\
\hline & $380 \pm 60$ & $503-325$ & 1448-1625 AD & $\mathrm{H} 2$ & 2 & 1.5 & \\
\hline \multirow{3}{*}{$\begin{array}{c}\text { Val de las } \\
\text { Lenas (4) Peña } \\
\text { Monné et al., } \\
1993\end{array}$} & $5910 \pm 270$ & $7154-6437$ & $5205-4488 \mathrm{BC}$ & H1A & 10.3 & 7 & \multirow{3}{*}{ ] 0.5} \\
\hline & $2470 \pm 150$ & $2718-2378$ & $769-429 \mathrm{BC}$ & $\mathrm{H} 1 \mathrm{C}$ & 10.3 & 9.1 & \\
\hline & $1960 \pm 210$ & 2289-1629 & 340 BC-322 AD & $\mathrm{H} 1 \mathrm{C}$ & 5 & 3.7 & \\
\hline \multirow{4}{*}{$\begin{array}{l}\text { Cuarte-Santa } \\
\text { Fe } \\
\text { (5) Peña Monné } \\
\text { et al., } 1998\end{array}$} & $4195 \pm 65$ & $4840-4627$ & 2891-2678 BC & H1A & 5 & 4.5 & \\
\hline & $3440 \pm 150$ & $3891-3495$ & $1942-1546$ BC & H1B & 5 & 4.5 & \\
\hline & $2420 \pm 170$ & $2733-2336$ & 784-387 BC & $\mathrm{H} 1 \mathrm{C}$ & 5 & 4 & \\
\hline & $500 \pm 150$ & $658-331$ & $1292-1620 \mathrm{AD}$ & $\mathrm{H} 2$ & 4.5 & 1.2 & \\
\hline \multirow{2}{*}{$\begin{array}{l}\text { Valmadrid } \\
\text { (6) Calvo and } \\
\text { Soriano, 1987; } \\
\text { Soriano, } 1989\end{array}$} & $2140 \pm 220$ & $2361-1825$ & 412 BC-125 AD & $\mathrm{H} 1 \mathrm{C}$ & 6 & 2 & \\
\hline & $2000 \pm 80$ & $2060-1868$ & $111 \mathrm{BC}-83 \mathrm{AD}$ & $\mathrm{H} 1 \mathrm{C}$ & 6 & 2 & \\
\hline \multirow{6}{*}{$\begin{array}{l}\text { (8) Constante } e t \\
\text { al., } 2010\end{array}$} & $7185 \pm 65$ & $8033-7950$ & 6084-6001 BC & H1A & 11.3 & 6.7 & \multirow{6}{*}{ ] 9} \\
\hline & $3285 \pm 60$ & $3566-3456$ & $1617-1507 \mathrm{BC}$ & H1B & 8 & 4.7 & \\
\hline & $3075 \pm 60$ & $3356-3231$ & $1407-1282 \mathrm{BC}$ & H1B & 8 & 2.7 & \\
\hline & $3135 \pm 50$ & $3442-3256$ & 1493-1307 BC & H1B & 4 & 3.5 & \\
\hline & $2855 \pm 50$ & $3059-2885$ & $1110-936$ BC & H1B & 6 & 5.2 & \\
\hline & $2645 \pm 50$ & $2840-2738$ & 891-789 BC & H1B & 6 & 3 & \\
\hline \multirow{4}{*}{$\begin{array}{l}\text { El Sisallar } \\
\text { (9) Constante et } \\
\text { al., } 2011\end{array}$} & $4285 \pm 60$ & $4965-4821$ & $3016-2872 \mathrm{BC}$ & H1A & 8.3 & 5.6 & \multirow{4}{*}{ ] 1.2} \\
\hline & $3535 \pm 60$ & $3893-3720$ & 1944-1771 BC & H1B & 8.3 & 4.2 & \\
\hline & $1570 \pm 55$ & $1526-1409$ & 425-541 AD & $\mathrm{H} 1 \mathrm{C}$ & 8.3 & 2 & \\
\hline & $1495 \pm 55$ & $1476-1312$ & 474-639 AD & $\mathrm{H} 1 \mathrm{C}$ & 8.3 & 1.8 & \\
\hline \multirow{2}{*}{$\begin{array}{l}\text { Val de Alfocea } \\
\text { (10) Constante } \\
\text { et al., } 2009\end{array}$} & $4270 \pm 55$ & 4956-4709 & $3007-2760$ BC & H1A & 8 & 7.5 & \multirow[b]{2}{*}{ ] 4} \\
\hline & $3610 \pm 60$ & 4061-3838 & 2112-1889 BC & H1B & 8 & 2.7 & \\
\hline \multirow{2}{*}{$\begin{array}{l}\text { Val de Nuez } \\
\text { (12) Constante } \\
\text { et al., } 2010 \\
\end{array}$} & $5140 \pm 60$ & $5986-5756$ & 4037-3807 BC & H1A & 7.5 & 3.8 & \\
\hline & $4675 \pm 60$ & 5469-5319 & $3520-3370$ BC & $\mathrm{H} 1 \mathrm{~A}$ & 6 & 4 & \\
\hline $\begin{array}{c}\text { Villafranca } \\
\text { (13) Arauzo and } \\
\text { Gutierrez, } 1994\end{array}$ & $3760 \pm 70$ & $4237-3991$ & $2288-2042$ BC & H1A & 6 & 2.4 & \\
\hline \multirow{2}{*}{$\begin{array}{l}\text { Val de Osera } \\
\text { (14) Arauzo and } \\
\text { Gutiérrez, } 1994\end{array}$} & $9865 \pm 85$ & $11396-11196$ & $9447-9247 \mathrm{BC}$ & H1A & 3 & 3 & \\
\hline & $3440 \pm 95$ & $3831-3593$ & 1882-1644 BC & H1B & 6.3 & 1.8 & \\
\hline \multirow{3}{*}{$\begin{array}{c}\text { Valsalada } \\
\text { (15) Sancho et } \\
\text { al., } 2007\end{array}$} & $10550 \pm 80$ & $12628-12418$ & $\begin{array}{c}10679-10469 \\
\text { BC }\end{array}$ & H1A & 4 & 2.6 & \\
\hline & $3225 \pm 50$ & $3547-3383$ & 1598-1434 BC & $\mathrm{H} 1 \mathrm{C}$ & 4.7 & 1.2 & \\
\hline & $1640 \pm 50$ & $1608-1419$ & $342-531 \mathrm{AD}$ & $\mathrm{H} 2$ & 5 & 0.5 & \\
\hline \multirow{5}{*}{$\begin{array}{l}\text { Valdezaragoza } \\
\text { (1) (2) This } \\
\text { paper }\end{array}$} & $4160 \pm 30$ & $4821-4628$ & $2872-2679 \mathrm{BC}$ & H1A & 8.35 & 5.35 & \\
\hline & $4153 \pm 30$ & $4820-4621$ & 2871-2672 BC & H1A & 3 & 2.7 & \\
\hline & $4090 \pm 29$ & $4785-4526$ & $2836-2571 \mathrm{BC}$ & H1A & 2.5 & 1.4 & \\
\hline & $1970 \pm 30$ & $1948-1882$ & $2-68 \mathrm{AD}$ & $\mathrm{H} 1 \mathrm{C}$ & 2.35 & 1.9 & \\
\hline & $100.16 \pm 0.36$ & $251-35$ & $1699-1915 \mathrm{AD}$ & $\mathrm{H} 2$ & 4 & 1.3 & \\
\hline
\end{tabular}

(*) location number Fig. 1c. Data about the thickness of the analysed outcrops, depth of the samples, and aggradational rates of some accumulations are indicated. 
The second accumulation period (H1B phase), recorded in the middle units of the $\mathrm{H} 1$ terrace fill, was formed in the transition between the Middle and the Late Holocene. From a cultural point of view, it covers the end of the Chalcolithic and the Bronze and Iron Ages, spanning from 4200 to 2500 BP (Fig. 11g). This age correlates with the dates obtained in other vales such as (Fig. 11c, Table 3), Val de La Virgen (between 2738 and 3456 cal yr BP), Sisallar (3893-3720 cal yr BP), and Alfocea (4061-3838 cal yr BP) (Constante et al., 2006, 2009, 2010, 2011), Villafranca de Ebro (4237-3991 cal yr BP) and Osera (3831-3593 cal yr BP) (Arauzo and Gutiérrez, 1994) (Ebro scarp) and the areas of Santa Fe (3891-3485 cal yr BP), Val de la Morera (3563-3410 cal yr BP) (Huerva River) (Peña Monné et al., 1998, 2004), and Valsalada (3547-3383 cal yr BP) (Sancho et al., 2007a). Similarly, at Bardenas Reales de Navarra, Sancho et al. (2008) dated this phase at 3270-3520 cal yr BP. This group of ages covers the end of the Subboreal period, with one Bond events (4.2) (Fig. 11a). It is also a phase with big cultural changes, like those of the Bronze and Iron Ages (Fig. 11g). During those ages, significant population growth was accompanied by constant technical improvement that led to greater pressure on the landscape and consequently, an increase in the erosion rate and infilling processes of the valleys (Fig. 11e). This period has not been dated at the Val de Zaragoza yet.

The end of $\mathrm{H} 1$ accumulation phase (H1C) spans from the end of the Iron Age-IberoRoman Epoch (5th century BC) to the Late Roman Epoch (5th century AD). At the Val de Zaragoza this accumulation is well represented with a date of $1970 \pm 30{ }^{14} \mathrm{C} \mathrm{yr} \mathrm{BP}$ (1948-1882 cal yr BP) and a large number of ceramic fragments of similar age. The same Roman end of the stage was observed at Valmadrid, SE Zaragoza, by Soriano and Calvo (1987) and Soriano (1989) (2361-1825 and 2060-1868 cal yr BP), at Val de las Lenas (2718-2378 cal yr BP, 2289-1629 cal yr BP), El Sisallar (1526-1409 cal yr BP, 1476-1312 cal yr BP), and Santa Fe (2733-2336 cal yr BP) by Peña Monné et al. (1993, 2001, 2004), at Valsalada (1608-1419 cal yr BP) by Sancho et al. (2008) (Fig. 11c, Table 3), and in the valley fills around Juslibol castle, in the Ebro scarp by Peña Monné (1996).

These datings are accompanied in the Val de Zaragoza (level B in Fig.7e), as well as in the Val de la Morera and Val de las Lenas, by deposits enriched with charcoals and ashes, and so indicating extensive fires. In addition, these deposits contain a large number of ceramic potsherds and ruins that evidence the strong human pressure on the landscape. In the Huerva Valley and Castillo de Juslibol, H1C is the thickest stage, showing the increasing land degradation while the deposit was forming (Constante and Peña-Monné, 2009; Peña Monné et al., 2014). Climatically, this stage was dominated by the Roman Warm Period (Fig. 11a), also favorable for degradational processes. In Val de Zaragoza, unit $\mathrm{C}$ of the Bastarás weir sector (Figs. 7d, e) reaches more than 1.5 $\mathrm{m}$ of fine sediments deposited since the 1 st century AD, but no further chronological data of the final layer is available. However, in the Huerva Valley (Val de las Lenas, Cuarte, and Val de la Morera) and Mediana de Aragón (Ginel River) (Burillo et al., 1985), the fills cover the Roman villae of later times (3rd and 4th centuries AD) (Peña Monné et al., 2004).

The subdivision of $\mathrm{H} 1$ aggradational phases is not necessarily similar across the entire region since it is strongly dependent on the local human impact. The erosive 
processes triggered by intense forest exploitation, fires, and agriculture had a major impact during the Bronze Age in some sectors (such as the Ebro scarp) (Constante et al., 2010), while in other places, such as the Huerva valley, the most significant anthropogenic activity correspond to Roman times (Peña Monné et al., 2004). The situation is similar at the Val de Zaragoza.

In the Ebro depression, after the formation of the Late Roman deposits (by the end of H1C) a remarkable dynamic change occurred after the 4th century AD and before Visigothic times, when incision processes on $\mathrm{H} 1$ deposits became dominant (Peña Monné et al., 2004). This is supported by the existence of graves from the 7 th century over those fills in the area of Cuarte (Gutiérrez Elorza and Peña Monné, 1998), which indicates that it had already become a non-functional level. According to its chronology (Fig. 11a), the incision phase may have been related to the environmental change caused by the cold and wet 1.4 Bond event (Bond et al., 1997) during the LALIA (Late Antique Little Ice Age, 530-660 AD) (Büntgen et al., 2016) or Dark Ages Cold Period (DCAP) (Helama et al., 2017).

\subsection{Accumulative stages $H 2$ and H3: Chronology and characteristics}

In the inner part of the present channel terrace surfaces $\mathrm{H} 2$ and $\mathrm{H} 3$ are inset on $\mathrm{H} 1$ terrace fill and separated by an intermediate incision phase (Fig. 11e). These recent aggradational and erosional stages have a less abundant record in the Ebro basin; this is because most of the vales are still filled by $\mathrm{H} 1$ deposits and only the lowest reaches closer to the main rivers are affected by an incision wave controlled by piping processes. Thus, $\mathrm{H} 2$ and $\mathrm{H} 3$ are often thin (1-3 m) and restricted to lower reaches. In Val de Zaragoza, Aldea del Correo, and in the sector of the weir of Bastarás, these stages are represented by slope and fluvial deposits inset and unconformably overlaying H1 deposits (Figs. 7a, e, 10b, c).

Their datings are scarce and problematic due to the impossibility of calibration. Traditionally, the H2 stage was considered "post-Medieval" because it had Medieval ceramics in several valleys of the Central Ebro Basin, and H3 stage was associated with part of the Little Ice Age (Peña Monné et al., 2004 and Pérez-Lambán et al., 2014). At present, it is possible to classify the datings into two groups that reflect the real chronology.

In the Val de la Morera (Huerva valley) a level was dated to 503-325 cal yr BP (Peña Monné et al., 2004) and in Santa Fe to 658-331 cal yr BP (Peña Monné et al., 1998). These datings are framed within H2 accumulations (LIA 1, Figs. 11a, b, c, Table 3), approximately correlated with the Spörer Minimum (1460 and 1550 AD), and characterized by wet and cold conditions in the Southern Pyrenees (Morellón et al., 2012). Moreover, the H3 stage (LIA 2, Fig. 11) was dated between $360 \pm 101$ cal yr BP and $216 \pm 89 \mathrm{cal} \mathrm{yr} \mathrm{BP}$ in the Bardenas Reales de Navarra (Sancho et al., 2007b). The only date (251-35 cal yr BP) obtained at Val de Zaragoza from a sequence of charcoal layers, near Aldea del Correo, also corresponds to stage H3 (Figs. 5c, d). The important contribution of charcoal and ashes incorporated to the H3 fill supports an increase in the erosion rates of the upper slopes during this time in response to an intense human impact on the basin landscape from the end of the 18th century to the first half of the 19th 
century with the aim of supplying charcoal to the growing city of Zaragoza. From the climatic point of view, the date of $\mathrm{H} 3$ terrace is coincident with the end of the LIA (Figs. 11a, e, f), probably related to the Dalton Minimum (1790-1830), with cold winters and increased snow in the south of the Pyrenees (Saz, 2007; Morellón et al., 2012) especially in high north-oriented areas, such as the Val de Zaragoza basin. The period was also characterized by events of strong precipitations, floods of the main rivers and also of the secondary courses, such as the vales (Peña Monné et al., 2004).

The increase in water availability must have inspired the owners of the Bastarás property to build a weir for irrigation in the Val de Zaragoza. The exact construction date is unknown because there are no documents. According to some references obtained from the owners of the land, the weir functioned until at least the middle of the 19th century. An important datum is that the walls protecting the channel downstream of the weir are on $\mathrm{H} 2$ terrace deposits. Therefore, they were constructed after $\mathrm{H} 2$ sedimentation but also after its incision. Besides, level H3 is laterally supported by these walls, so it fits well chronologically into the calculated time of construction.

The information obtained from the Holocene accumulations from Val de Zaragoza allowed getting an almost complete evolutionary Holocene sequence. However, it was not possible to establish the aggradation rates of the different units. This is because there are no datings at different depths on each outcrop. Moreover, according to the characteristics of the studied profiles, they values would not be accurate due to the inner erosive discordances observed. In the table 3 the thickness of the outcrops and the depth of the samples were introduced for all cases from the Ebro Basin. Only in the case of Val de la Morera, Val de las Lenas, Val de la Virgen, El Sisallar, and Val de Alfocea was possible to establish partial accumulation rates. They range between 0.5 and $12.2 \mathrm{~m} / 1000 \mathrm{yrs}$. If we have into consideration that in some cases (Val de las Lenas, la Morera, and de la Virgen) the upper layers could be dated with Roman archaeological materials from 4th to 5th centuries AD (Peña Monné et al., 1993, 1998, 2001, 2004), the accumulation rates would be between 2 and $3 \mathrm{~m} / 1000$ yrs for the unit H1, with a maximum in the H1C unit. This data was taken as the mean value for the graph represented in Fig. 11e although it only has a general indicative value.

\section{Conclusions}

The Val de Zaragoza is a small valley that well represents the hydrological and geomorphological functioning of the fluvial courses in the central sector of the Ebro basin during the Holocene. The cartography and study of several stratigraphic profiles of the valley and its tributaries made it possible to identify an extended and thick H1 accumulation, as well as two nested fluvial terraces forming $\mathrm{H} 2$ and $\mathrm{H} 3$ accumulations, separated by incision phases. The radiocarbon datings and archaeological remains from two phases enabled establishing correlations with other similar valleys in the Ebro basin.

The relationship of the Val de Zaragoza with the data from different nearby areas enabled to establish a regional evolutionary sequence composed of stages of accumulation and degradation. The first stage (H1) stands out, spanning from the Early Holocene to the 
Roman Epoch. It was possible to differentiate three aggradational phases: H1A (138004200 BP), H1B (4200-2500 BP), and H1C (2500-1500 BP). The morphosedimentary and chronological description of the profiles located in Aldea del Correo and the Bastarás weir only yielded data about phases A and C. Other data from valleys in the central Ebro basin shows an increase in the sedimentation rate of the basin between the oldest dates (from the Chalcolithic-Bronze Age) until a maximum with the highest values during the Iberian and Roman periods, when human pressure on the landscape was greater.

Accumulation stages $\mathrm{H} 2$ and $\mathrm{H} 3$ are restricted to the inner part of the incisions dated after the Roman Epoch and generated on $\mathrm{H} 1$ deposits. The scarce data available on the central sector of the Ebro depression, together with the radiocarbon dating obtained in Val de Zaragoza, enable us to locate the formation of $\mathrm{H} 2$ in the first phase of the LIA ( $c a$. 16th century) and H3 to a second climatic phase of the same period (the end of the 19th and beginning of the 20th centuries), both associated with climatic causes. Moreover, the presence in Val de Zaragoza of several layers with charcoal in this second phase is probably related to charcoal exploitation.

The construction of the Bastarás weir and the artificial channel network is a good testimony of the climatic influence of the LIA. The increase in water availability made it possible to manage water for irrigation and today this land is a rainfed area. The stone fences that were also needed at that time enabled us to increase our chronological knowledge of the evolution of $\mathrm{H} 2$ and $\mathrm{H} 3$ stages, and infer that water flow was greater than at present.

The geoarchaeological approach to the study of the Val de Zaragoza in the evolutionary framework of the central sector of the Ebro basin is shown as a key tool for gaining an understanding of current landscapes establishing chronological milestones and defining the role of man in triggering many of the key geomorphological processes.

\section{Acknowledgements}

This paper was carried out within the scope of the Quaternary Palaeoevironments Research Group PALEOQ of the Aragón Government and European Regional Development Fund and IUCA (Environmental Sciences Institute of the University of Zaragoza). Financial support received from MINECO HAR2015-65620-P Project and Ibercaja-CAI Program Research Stays. Research project HAR2014-59042-P funded by MINECO and Consolidated Research Group H07-PPVE funded by Government of Aragon and European Social Fund.

\section{References}

Alonso-Zarza, A.M., Armenteros, I., Braga, J.C., Muñoz, A., Pujalte, V., Ramos, E. 2002 Tertiary. In: W. Gibbons, T. Moreno (Eds.), The Geology of Spain. The Geological Society of London, pp. 293-324.

Arauzo, T., Gutiérrez, M. 1994. Evolución de los valles de fondo plano del centro de la Depresión del Ebro. In: J. Arnáez, J.M. García-Ruiz, A. Gómez-Villar (Eds.), Geomorfología en España. III Reunión Nacional de Geomorfología, Logroño, pp. 277-290. 
Bintliff, J. 2002. Time, process and catastrophism in the study of Mediterranean alluvial history: a review. World Archaeology 33, 417-435. https://doi.org/10.1080/00438240120107459.

Bond, G., Showers, W., Cheseby, M., Lotti, R., Almasi, P., de Menocal, P. Priore, P., Cullen, H., Hajdas, I., Bonani, G. 1997. A pervasive millennial-scale cycle in north Atlantic Holocene and glacial climates. Science 278, 1257-1266. https://doi.org/10.1126/science.278.5341.1257.

Burillo, F., Gutiérrez, M., Peña Monné, J.L. 1985. Las acumulaciones holocenas y su datación arqueológica en Mediana de Aragón (Zaragoza). Cuadernos de Investigación Geográfica 11, 193-207. https://doi.org/10.18172/cig.955.

Brïckner,H. 1986. Man's impact on the evolution of the physical environment in the Mediterranean region in historical times. GeoJournal 13 (1), 7-17. https://doi.org/10.1007/BF00190684.

Büntgen, U., Myglan, V.S., Ljungqvist, F.C., McCormick, M., Di Cosmo, N., Sigl, M. Jungclaus, J., Wagner, S., Krusic, P.J., Esper, J., Kaplan, J.O., De Vaan, M.A.C., Luterbacher, J., Wacker, L., Tegel, W., Kirdyanov, A.V. 2016. Cooling and societal change during the Late Antique Little Ice Age from 536 to around 660 AD. Nature Geoscience 9, 231-236. https://doi. org/10.1038/ngeo2652.

Butzer, K.W. 2005. Environmental history in the Mediterranean world: Cross-disciplinary investigation of cause-and-effect for degradation and soil erosion. Journal of Archaeological Science 32, 1773-1800. https://doi.org/10.1016/j.jas.2005.06.001.

Constante, A., Dossche, R., Peña Monné, J.L., Sancho, C., de Dapper, M. 2006. Dinámica morfosedimentaria holocena en laderas y valles del escarpe de Alfocea-Juslibol (sector central de la Depresión del Ebro). In: A. Pérez Alberti, J. López Bedoya (Eds.), Geomorfología y territorio. Santiago de Compostela, pp. 979-992.

Constante, A., Dossche, R., Peña-Monné, J.L., Sancho, C., de Dapper, M. 2009. Holocene evolution and geoarchaeology in the Ebro valley around Zaragoza (Northern Spain). In: M. De Dapper, F. Vermeulen, S. Deprez, D. Taelman (Eds.), Ol'man river Geo-archaeological aspects of rivers and river plains. Academia Press, Ghent, pp. 241-256.

Constante, A., Peña-Monné, J.L. 2009. Human-induced erosion and sedimentation during the Holocene in the central Ebro depresión, Spain. In: A. Romero, F. Belmonte, F. Alonso, F. López-Bermúdez (Eds.), Advances in studies on desertification. Universidad de Murcia, pp. 207-210.

Constante, A., Peña Monné, J.L., Muñoz, A. 2010. Alluvial geoarchaeology of an ephemeral stream: Implications for Holocene landscape change in the Central part of the Ebro Depression, Northeast Spain. Geoarchaeology 25, 475-496. https://doi.org/10.1002/gea.20314.

Constante, A., Peña Monné, J.L., Muñoz, A., Picazo, J. 2011 .Climate and anthropogenic factors affecting alluvial fan development during the Late Holocene in the Central Ebro valley, Northeast Spain. The Holocene 21, 275-286. https://doi.org/10.1177/0959683610378873.

Costa, J.M., Ramírez Merino, J.I., Salazar, A. 1998. Mapa Geológico de España escala 1:5000. Hoja 356 Lanaja. IGME, Madrid.

Domínguez Arranz, M.A., Magallón, M.A., Casado López, M.P. 1984. Carta Arqueológica de España: Huesca. Diputación Provincial, Huesca.

García Esteban, L., Guindeo Casasús, A., Peraza Oramas, C., de Palacios, P. 2003. La madera y su anatomía. Anomalías y defectos, estructura microscópica de coníferas y frondosas, identificación de maderas, descripción de especies y pared celular. Mundi-Prensa, Madrid.

Giral Royo, F. 2004. Introducción al poblamiento de época romana en Los Monegros. Revista d'Arqueología de Ponent 14, 223-236.

Gregory, K.J., Walling, D.E. 1973. Drainage basin. Form and process: a geomorphological approach. London. Edward Arnold. 
Gutiérrez Elorza, M., Peña Monné, J.L. 1998. Geomorphology and Late Holocene Climatic Change in Northeastern Spain. Geomorphology 23, 205-217. https://doi.org/10.1016/S0169555X(98)00004-X.

Helama, S., Jones, P.D., Briffa, K.R. 2017. Dark Ages Cold Period: A literature review and directions for future research. The Holocene 1-7. https://doi.org/10.1177/0959683617693898.

Lasaosa, R. 1997. Lanaja. La vida en un pueblo de Monegros antes de los regadíos. Edición La Val de Onsera, Huesca. Spain.

Mattingly, H., Sydenham, E.A. 1968. Roman Imperial Coinage, vol. 2, Vespasian to Hadrian. Spink \& Son, London.

Morellón, M., Pérez-Sanz, A., Corella, J.P., Büntgen, U., Catalán, J., González-Sampériz, P., González-Trueba, J.J., López-Saéz, J.A., Moreno, A., Pla-Rabes, S., Saz-Sánchez, M.A., Scussolini, P., Serrano, E., Steinhilber, F., Stefanova, V., Vegas-Villarubia, T., Valero-Garcés, B. 2012. A multi-proxy perspective on millennium-long climate variability in the Southern Pyrenees. Climate of the Past 8, 683-700. https://doi.org/10.5194/cp-8-683-2012.

Morisawa, M. 1985. Rivers. Form and process. In: K.M. Clayton (Ed.), Geomorphology texts. University of East Anglia.London and New York.

Peña Monné, J.L. 1996. Los valles holocenos del escarpe de yesos de Juslibol (sector central de la Depresión del Ebro). Aspectos geomorfológicos y geoarqueológicos. Arqueología Espacial $15,83-102$.

Peña Monné, J.L. 1997. Cartografía geomorfológica básica y aplicada. Geoforma Ediciones, Logroño, $227 \mathrm{pp}$.

Peña Monné,J.L.,Chueca, J., Julián,A., Echeverría, M.T. 1996. Reconstrucciones paleoambientales en el sector central de la Depresión del Ebro a partir de rellenos de valle y conos aluviales. In: A. Pérez-Alberti, P. Martini, W. Chesworth, A. Martínez-Cortizas (Eds.), Dinámica y evolución de medios cuaternarios. Xunta de Galicia, Sanbtiago de Compostela, pp. 291-307.

Peña Monné, J.L., Echeverría, M.T., Chueca J., Julián, A. 2001. Processus géomorphologiques d'accumulation et incision pendant l'Antiquité Classique et ses rapport avec l'activité humaine et les changements climatiques holocènes dans la vallée de la Huerva (Bassin de 1’Ebre, Espagne). In: F. Vermeulen, M. de Dapper (Eds.), Geoarchaeology of the Landscapes of Classical Antiquity. Leuven, Belgium, pp. 151-159.

Peña Monné, J.L., Echeverría, M.T., Petit-Maire, N., Lafont, R. 1993. Cronología e interpretación de las acumulaciones holocenas de la Val de las Lenas (Depresión del Ebro, Zaragoza). Geographicalia 30, 321-332.

Peña Monné, J.L., Julián, A., Chueca, J., Echeverría, M.T. 1998. Los estudios geoarqueológicos en la reconstrucción del paisaje. Su aplicación en el valle bajo del río Huerva. Arqueología Espacial 19-20, 169-183.

Peña Monné, J.L., Julián, A., Chueca, J., Echeverría, M.T., Ángeles, G. 2004. Etapas de evolución holocena en el valle del río Huerva: Geomorfología y Geoarqueología. In: J.L. Peña Monné, L.A. Longares, M. Sánchez-Fabre (Eds.), Geografía Física de Aragón. Aspectos generales y temáticos. Universidad de Zaragoza e Institución Fernando el Católico, pp. 289-302.

Peña Monné, J.L., Rubio, V., González, J.R. 2005. Aplicación de modelos geomorfológicos evolutivos al estudio de yacimientos arqueológicos en medios semiáridos (Depresión del Ebro, España). X Coloquio Ibérico de Geografía. A Geografia ibérica no cotexto europeo (15 p.) Évora, CD.

Peña-Monné, J.L., Sampietro-Vattuone, M.M. 2014. Geoarchaeological and paleoenvironmental reconstruction through evolutionary models: Dryland applications. European Geologist Magazine 38, 40-44.

Peña Monné, J.L., Sancho, C., Muñoz, A., Benito, G., Longares, L.A., McDonald, E., Rhodes, E. 2006. Morfoestratigrafía del registro aluvial Pleistoceno superior-Holoceno del Barranco 
Grande (Bardenas Reales): aproximación a su significado paleoambiental. In: A. PérezAlberti, J. López-Bedoya (Eds.), Geomorfología y Territorio. Universidad de Santiago de Compostela, pp. 655-668.

Peña Monné, J.L., Sancho, C., Muñoz, A., Constante, A. 2014. Clima y hombre en la evolución de las vales del sector central de la Depresión del Ebro durante el Holoceno superior. In: J. Arnáez, P. González-Sampériz, T. Lasanta, B.L. Valero (Eds.), Geoecología, cambio ambiental y paisaje: Homenaje al profesor José María García Ruiz, Inst. Pirenaico de Ecología, Universidad de La Rioja, 91-102.

Pérez-Lambám, F., Peña-Monné, J.L., Fanlo, J., Picazo, J.V., Badia, D., Rubio, V., GarcíaJiménez, R., Sampietro-Vattuone, M.M. 2014. Paleoenvironmental and geoarchaeological reconstruction from late Holocene slope records (Lower Huerva Valley, Ebro Basin, NE Spain). Quaternary Research 8, 1-14. https://doi.org/10.1016/j.yqres.2013.10.011.

Pope, K.O., van Andel, T.H. 1984. Late Quaternary alluviation and soil formation in the southern Argolid: its history, causes and archaeological implications. Journal of Archaeological Science 11, 281-306. https://doi.org/10.1016/0305-4403(84)90012-8.

Quirantes, J. 1978. Estudio sedimentológico del Terciario continental de los Monegros. Institución Fernando el Católico, Zaragoza.

Rasmussen, S.O., Vinther, B.M., Clausen, H.B., Andersen, K.K. 2007. Early Holocene climate oscillations recorded in three Greenland ice cores. Quaternary Science Reviews 26, 1907 1914. https://doi.org/10.1016/j.quascirev.2007.06.015.

Riba, O., Reguant, S., Villena, J. 1983. Ensayo de síntesis estratigráfica y evolutiva de la cuenca terciaria del Ebro. In: Libro Jubilar J.M. Ríos, Instituto Geológico Minero de España, Madrid, pp. 131-159.

Salvany, J.M., García-Veigas, J., Ortí, F. 2007. Glauberite-halite association of the Zaragoza Gypsum Formation (Lower Miocene, Ebro Basin, NE Spain). Sedimentology 54, 443-467. https://doi.org/10.1111/j.1365-3091.2006.00844.x.

Sancho, C., Muñoz, A., Peña Monné, J.L., González, P. 2007a. Evolución morfosedimentaria del sistema aluvial de Valsalada (Leciñena, Los Monegros) durante el Pleistoceno superiorHoloceno: aproximación paleoambiental. Geogaceta 41, 199-202.

Sancho, C., Benito, G., Peña Monné, J.L., Longares, L.A., McDonald, E., Rhodes, E., Saz, M.A. 2007b. Actividad aluvial durante la Pequeña Edad del Hielo en Bardenas Reales de Navarra. Geogaceta 42, 111-114.

Sancho, C., Peña Monné, J.L., Muñoz, A., Benito, G. McDonald, E., Rhodes, E., Longares, L.A. 2008. Holocene alluvial morphopedosedimentary record and environmental changes in the Bardenas Reales Natural Park (NE Spain). Catena 73, 225-238. https://doi.org/10.1016/j. catena.2007.09.011.

Saz, M.A. 2007. Evolución de las temperaturas medias de la estación cálida (abril-septiembre) en la mitad norte de España durante la Pequeña Edad del Hielo (siglos XVI al XIX). Geographicalia 52, 143-163.

Schweingruber, F.H. 1990. Anatomie Europäischer Hölzer. Haupt, Bern und Stuttgart.

Soriano, M.A. 1989. Infilled valleys in the Central Ebro Basin (Spain). Catena 16, 357-367. https:// doi.org/10.1016/0341-8162(89)90020-9.

Soriano, M.A., Calvo, J.M. 1987. Características, datación y evolución de los valles de fondo plano de las inmediaciones de Zaragoza. Cuaternario y Geomorfología 1, 283-293.

Strahler, A.N. 1964. Quantitative geomorphology of drainage basins and channel networks. Section 4-II of Handbooks of Applied Hydrology, McGraw-Hill Book Co., New York.

Vernet, J.L. 1973. Étude sur l'histoire de la végétation du Sud-Est de la France au Quaternaire d'après l'étude des charbons de bois principalement. Paléobiologie Continentale 4, 1-90. 
Vernet,J.L., Ogereau,P., Figueiral,I., Machado Yanes, C., Uzquiano, P. 2001. Guide d'identification des charbons de bois préhistoriques et récents. Sud-Ouest de l'Europe: France, Péninsule ibérique et îles Canaries. CNRS, París.

Van Zuidam, R.A. 1975. Geomorphology and Archaeology. Evidences of interrelation at historical sites in the Zaragoza region, Spain. Zeitscrift fur Geomorphologie 19, 319-328.

Vita-Finzi,C. 1969. The Mediterranean valleys. Geological changes in historical times. Cambridge University Press, Cambridge, $140 \mathrm{pp}$. 